\title{
Appraisal of Anti-Arthritic Potential of Quercus Leucotrichophora Methanolic Extract in Complete Freund's Adjuvant Induced Arthritic Rats; a Mechanistic Study
}

\author{
Ammara Saleem ( $\square$ amarafurqan786@hotmail.com ) \\ Izza Hameed \\ Government College University Faisalabad \\ Muhammad Furqan Akhtar \\ Riphah International University - Lahore Campus \\ Md. Habibur Rahman \\ Southeast University \\ Ghulam Md Ashraf \\ King Abdulaziz University
}

Government College university faisalabad https://orcid.org/0000-0002-2478-7800

\section{Research Article}

Keywords: Quercus leucotrichophora, Carrageenan induced paw edema, oxidative stress biomarkers, Complete Freund's Adjuvant, HPLC

Posted Date: January 4th, 2022

DOI: https://doi.org/10.21203/rs.3.rs-1214323/v1

License: (c) (i) This work is licensed under a Creative Commons Attribution 4.0 International License. Read Full License 


\section{Abstract}

This research work was conducted to validate the folkloric use and therapeutic potential of Quercus leucotrichophora (QL) leaf methanolic and aqueous extracts against inflammation and arthritis and to determine the chemical composition by HPLC. The in-vitro anti-oxidant and anti-inflammatory activities were carried out along with in-vivo assays such as carrageenan induced paw edema, xylene induced ear edema and Complete Freund's Adjuvant induced arthritis in Wistar rats. The CFA (0.1 ml) was inoculated to the left hind paw at day 1 to induce arthritis and oral dosing with QLME at 150,300 and $600 \mathrm{mg} / \mathrm{kg}$ was begun at $8^{\text {th }}$ day till the $28^{\text {th }}$ day in all groups while methotrexate was given as standard treatment. There was a noteworthy $(p<0.05-0.0001)$ restoration in body weight, paw edema, arthritic index, altered blood parameters and oxidative stress biomarkers in treated rats as compared to diseased group. Moreover, QLME considerably ( $p<0.0001$ ) downregulated TNF-a, IL-6, IL-1 $\beta$, COX-2, and NF-kB, while significantly $(p<0.0001)$ upregulated IL-10, I-KB, IL-4 in relation to diseased group. The QLME exhibited no mortality in acute toxicity study. It was concluded that QLME possessed substantial anti-inflammatory and anti-arthritic potential at all dosage levels, mainly at $600 \mathrm{mg} / \mathrm{kg}$ might be due to presence of quercetin, sinapic acid and ferulic acid.

\section{Introduction}

Inflammation is thought to be a body's non-specific immune response as a result of infection, injury or detection of foreign invasion by microbes, instructing immune response or healing. The process of inflammation can be assessed by major cardinal signs at tissue level that includes tumor, calor, rubor, dolor and function laesa (Stankov 2012).

Rheumatoid arthritis (RA), a chronic inflammatory auto-immune syndrome of intricate etiology, is symbolized by morning stiffness, fatigue, persistent swelling of joint, erosive synovitis, and joint rigidity that begins predominantly in small diarthrodial joints of hands and feet. It affects $0.5-1 \%$ adult population worldwide. Its susceptibility increases with age. The risk factors for RA include diet, smoking, hormones, caffeine and genetic abnormalities (Firestein 2003; Oliver \& Silman 2006).

The RA is a multifaceted disease that is clinically identified by the existence of rheumatoid factor (RF) or anti-citrullinated protein antibody in the sera of affected persons. There is also an augmented discharge of pro-inflammatory cytokines for instance, tumor necrosis factor (TNF)-a, interleukin (IL)-6,1 $\beta$, and metabolic enzymes like cyclooxygenase (COX)-2 and lipoxygenases (LOX) from activated immune cells. Though, the level of anti-inflammatory cytokines (IL-4 and 10) is decreased (Harrison et al. 2021; Zhang 2021). The oxidative stress is another trigger for RA in addition to pro-inflammatory cytokines.

The management of RA includes medications, physiotherapy, counseling of patient, nutrition and surgery. The medications include Non-steroidal anti-inflammatory drugs NSAIDs (Diclofenac, ibuprofen and piroxicam), glucocorticoids (prednisolone and dexamethasone), biologics, anti-TNF-a, gold compounds, and Disease modifying anti-rheumatic drugs (DMARDs) (Placha \& Jampilek 2021). As RA is not curable 
so its lifelong therapy is expensive and complicated with various adverse effects such as ulceration, bone marrow depression, cardiovascular disorders, hypertension, hepatic damage and nephrotoxicity. The practice of using medicinal plants for the treatment of arthritis provides preferable alternative due to low cost, easy approach and minimum harmful implications (Shabbir et al.2018).

Quercus leucotrichophora (QL) belongs to Fagaceae family. It is a deciduous evergreen tree and commonly called as "Rein". The genus Quercus includes about 450 species. The QL is widespread in Asia, Europe, North Africa, Central and South America among other trees of this genus. QL grows in temperate and tropical climatic regions and is used as an indigenous medicine for RA in Rawalpindi district, Pakistan. Over the centuries, the various species of genus Quercus (Q. dilatata and Q. incana) are traditionally utilized for the treatment of pain, inflammation and arthritis (Moreno-Jimenez et al. 2015); (Taib et al. 2020).

The plant QL is used as a folkloric remedy to treat rheumatism, asthma, backache, cough, fever and joint pain. Its bark and leaf contained 23 and 62 constituents respectively, with profound anti-bacterial activity (Semwal et al. 2018). It has significant antioxidant and hepato-protective activity (Singh \& Bisht 2018). The literature survey showed that the anti-arthritic potential of QL was not scientifically validated. Therefore, the current study aimed to evaluate the anti-inflammatory and anti-arthritic potential of QL extracts by in vitro and in vivo methods. Moreover, acute toxicity testing and chemical characterization of the plant extracts were also investigated.

\section{Materials And Methods}

\section{Sample preparation}

The leaves of QL were collected in November, 2020 from Murree, Pakistan and were identified by taxonomist at University of Agriculture, Faisalabad (Voucher No. 1117-20-5b) and the sample was submitted for future referencing.

The leaves $(5 \mathrm{~kg}$ ) of QL were washed to eliminate dust and foreign particles, then dried under shade and ground to form coarse powder. The methanol and aqueous extracts of QL (QLME and QLAQ) were prepared by cold maceration process. The powdered plant was soaked in methanol (1:10) for 14 days with occasional shaking daily. The filtration was completed and the process was repeated twice. Finally, filtrates were gathered and dense by the rotary evaporator at $45^{\circ} \mathrm{C}$. It was then air dried to solid or semisolid form. The same process was done for preparing the QLAQ extract.

\section{Animals for experimentation}

Healthy Wistar rats of both sexes (120-170 g) were acquired and kept at the Animal house of the Department with the continuous supply of water and a standard pellet diet. The animals were held in cycles of $12 \mathrm{~h}$ of light/ dark at standard humidity $(60-70 \%)$ and temperature $\left(28-30^{\circ} \mathrm{C}\right)$. All animals were acclimatized for one week prior to the study. The approval for animal testing was acquired from The 
Ethical Committee of Animals, GCUF (Voucher \# GCUF/ERC/2220). Undue damage to the animals was evaded.

\section{Qualitative and quantitative analysis}

The QL extracts were evaluated for phytochemicals like alkaloids, tannins, phenols, saponins, flavonoids, steroids, terpenoids, proteins and glycosides by standard procedures (Saleem et al. 2020a).

For the determination of total phenolic contents (TPC), extract $(0.5 \mathrm{ml})$ was mixed with $2.2 \mathrm{ml}$ of distilled water (DW) and $0.15 \mathrm{ml}$ of $5 \% \mathrm{NaNO}_{2}$ solution. Then after $6 \mathrm{~min}, 0.3 \mathrm{ml}$ of $10 \% \mathrm{AlCl}_{3} \cdot 6 \mathrm{H}_{2} \mathrm{O}$ was mixed and left for $5 \mathrm{~min}$. Then $1 \mathrm{ml}$ of $1 \mathrm{~N} \mathrm{NaOH}$ solution was added and vortexed, later the absorbance was taken at $510 \mathrm{~nm}$. Gallic acid was used as standard (Saleem et al. 2020b).

For total flavonoid contents (TFC), the stock sample $(10 \mathrm{mg} / \mathrm{ml})$ of $100 \mu \mathrm{l}$ was added to $2 \mathrm{ml}$ of $2 \%$ $\mathrm{Na}_{2} \mathrm{CO}_{3}$ and left for $2 \mathrm{~min}$ at room temperature. Afterwards, $100 \mu \mathrm{l}$ of $50 \%$ Folin-Ciocalteu's reagent was added. Catechin was used as reference. After $30 \mathrm{~min}$ incubation at room temperature, absorbance was determined at $765 \mathrm{~nm}$ (Cheruth et al. 2016).

\section{High performance liquid chromatography (HPLC) analysis}

The HPLC analysis of QLME and QLAE was performed by the previous procedure (Asif et al. 2020). The sample preparation was done by adding $10 \mathrm{mg}$ of extract in $5 \mathrm{ml} \mathrm{DW}$ and then ethanol $12 \mathrm{ml}$ was mixed. After $5 \mathrm{~min}, 6 \mathrm{ml} \mathrm{DW}$ was added and paused for $5 \mathrm{~min}$ along with the addition of $10 \mathrm{ml}$ of $15 \mathrm{M} \mathrm{HCl}$ and then placed in the oven for $2 \mathrm{~h}$ at $90^{\circ} \mathrm{C}$. Syringe filter was used for injection of the sample into HPLC. The separation of compounds was done by using Shim-Pack Column (Shimadzu, Japan) CLC-ODS. The mobile phase included methanol and acetonitrile in 30:70 as solvent $A$, while double DW with glacial acetic acid $(0.5 \%)$ as solvent B. The UV-visible detector (SPD-10AV) was used at $280 \mathrm{~nm}$ wavelength. The retention time of standards was used to identify and quantify detected compounds.

\section{In-vitro evaluation}

\section{2,2-diphenyl-1-picrylhydrazyl (DPPH) scavenging assay}

For this, $2 \mathrm{ml}$ DPPH solution (0.04/100 mg methanol) was mixed in $1 \mathrm{ml}$ solution of plant extract and 1 $\mathrm{ml}$ of methanol. The twofold dilution method was used to prepare the sample solution of extracts in methanol. Absorbance was taken after $30 \mathrm{~min}$ at $517 \mathrm{~nm}$ using ascorbic acid as a reference (Saleem et al. 2020a). The \% DPPH radical scavenging of the mean was calculated.

\section{Inhibition of protein denaturation assay}

In egg albumin (EA) denaturation assay, a $5 \mathrm{ml}$ reaction mixture contained $0.2 \mathrm{ml}$ of EA (from fresh egg of hen), phosphate buffered saline $2.8 \mathrm{ml}$ (PBS) of pH 6.4 and $2 \mathrm{ml}$ of plant extracts $(50,100,200,400$, $800 \& 1600 \mu \mathrm{g} / \mathrm{ml}$ ), while same volumes of piroxicam solution and DW were used as standard and 
control solutions respectively in place of extract solutions. Afterwards, these mixtures were incubated for $15 \mathrm{~min}$ at $37 \pm 2^{\circ} \mathrm{C}$. Later, warmed for $5 \mathrm{~min}$ at $70^{\circ} \mathrm{C}$. The absorbance of mixture was taken at $660 \mathrm{~nm}$ (Akhtar 2020).

For the BSA denaturation assay, an earlier procedure was followed (Saleem et al. 2019). Briefly, test control $(0.5 \mathrm{ml})$ contained $0.45 \mathrm{ml} \mathrm{BSA}(5 \% \mathrm{w} / \mathrm{v})$ and $0.05 \mathrm{ml}$ of extract dilutions. The product control solution contained DW $(0.45 \mathrm{ml})$ in place of BSA solution. Standard solution contained piroxicam instead of extract solution. The pH was adjusted to 6.3 and incubated for $20 \mathrm{~min}$ at $37 \mathbb{C}$ afterward, heated at $57^{\circ} \mathrm{C}$ for $3 \mathrm{~min}$. The absorbance was taken at $660 \mathrm{~nm}$.

\section{Human red blood cells (HRBC) membrane stabilization assay}

This assay was performed according to a previous procedure (Saleem et al. 2019). In short, $3 \mathrm{ml}$ blood from healthy volunteer was mixed with Alsever's solution and RBCs suspension (10\% v/v) was prepared using isosaline solution after centrifugation at $3000 \mathrm{rpm}$ for $15 \mathrm{~min}$.

Test solution contained phosphate buffer $(1 \mathrm{ml})$, hypotonic saline $(2 \mathrm{ml}), 0.5 \mathrm{ml}$ extract and $10 \%$ human red blood cells $(0.5 \mathrm{ml})$. Test control solution contained DW while the standard solution contained piroxicam instead of extract. The solutions were incubated for $30 \mathrm{~min}$ at $37^{\circ} \mathrm{C}$ after that centrifugation at $3000 \mathrm{rpm}$ for $15 \mathrm{~min}$. The sample absorbance was taken at $560 \mathrm{~nm}$ and \% protection was calculated.

\section{Study design for in-vivo evaluation}

The Wistar rats (120-170 g) were indiscriminately allocated into six groups $(n=6)$, Group I served as normal control (NC) and was provided with DW. Group II was disease control (DC) and provided with DW. Group III was standard control (SC) and given piroxicam (10 mg/kg). Group IV, V and VI received with QLME and QLAQ at 150, 300 and $600 \mathrm{mg} / \mathrm{kg}$ via oral route respectively.

\section{Xylene induced ear edema}

An earlier procedure was adopted for xylene induced ear edema (Shabbir et al. 2018). Briefly, a drop of xylene was applied to right ear's inner surface of each animal except NC, 30 min post-administration of the above treatments. Afterwards, the anesthetized rats were slaughtered after $15 \mathrm{~min}$ to remove and weigh both ears. The percentage inhibition was calculated.

Increase in weight = right ear weight - left ear weight

$\%$ inhibition $=(C-T) /(C) \times 100$

C: control; T: treatment

\section{Carrageenan induced paw edema}

The rats in all groups were treated as aforementioned. One hour later, $0.1 \mathrm{ml}$ carrageenan $(1 \% \mathrm{w} / \mathrm{v})$ solution was administered via sub-cutaneous injection in left hind paw (sub-plantar region) of all rats 
except NC. Paw diameter $(\mathrm{mm})$ was measured at $0,1,2,3,4$ till 8 th hour using a digital Vernier caliper (Shabbir et al. 2018).

\section{Complete Freund's Adjuvant (CFA) induced arthritis}

The results of in-vitro anti-oxidant and anti-inflammatory studies along with acute in-vivo antiinflammatory studies revealed that QLME effectively reduced free radicals and showed profound antiinflammatory activity than QLAQ. Therefore, QLME was further evaluated by using CFA induced arthritic model.

At day 1, $0.1 \mathrm{ml}$ CFA (Sigma Aldrich ${ }^{\circledR}$, UK) was injected in sub-plantar region of the left hind paw in all except normal control rats (Han et al. 2016). The study design was same as above mentioned except SC was treated with methotrexate (MTX) $(1 \mathrm{mg} / \mathrm{kg} /$ week) by intraperitoneal route. Treatment groups received QLME at 150,300 and $600 \mathrm{mg} / \mathrm{kg} /$ day via oral gavage from 8 to till 28th day (21 days).

\section{Arthritis evaluation}

The body weight and diameter of the left hind paw was determined before first immunization and then at $7,12,16,20,24$, and 28 th day post-CFA administration. The percentage inhibition of paw edema was measured. The severity of arthritis was assessed by an arthritic scoring system that ranged from 0 to 4 scales. In arthritic scoring, 0 and 1 and 2 meant no swelling, swelling of toe joints and swelling of both toes and toe joints respectively. Moreover, 3 and 4 meant ankle joint swelling and entire paw swelling leading to immobility respectively (Han et al. 2016).

\section{Hematological and biochemical evaluation}

After 28th day, the blood was collected by cardiac puncture in plain and EDTA containing tubes from anesthetized rats. The commercially available kit (Antec Diagnostic Products ${ }^{\circledR}$, UK) was utilized to determine RF, alanine aminotransferase (ALT), Aspartate aminotransferase (AST), Alkaline phosphatase (ALP), while automated chemistry analyzer (Microlab $300 \AA$, Germany) was used for urea and creatinine determination. The automated hemocytometer (Sysmex, Roche ${ }^{\circledR}$, Germany) was used to count complete blood count (CBC).

\section{Immune organ and histopathological evaluation}

The blood collected by cardiac puncture in EDTA tube was processed for RNA extraction. The abdomen was dissected to remove the spleen and thymus, which were then washed with DW and weighed (Saleem et al. 2020c). For histopathological evaluation, left hind limb ankle joints were removed, rinsed with DW and placed for $24 \mathrm{~h}$ in $10 \% \mathrm{v} / \mathrm{v}$ neutral buffered formalin. The decalcification of joints was done by decalcifying solution ( $10 \% \mathrm{w} / \mathrm{v}$ EDTA). After mounting on slides, the tissues were stained and slides were observed for histopathological changes under light microscope at 40X (Shabbir et al. 2018).

\section{Quantification by real time (RT)-PCR}


For the estimation of IL-4, IL-10, IL-6, IL-1 $\beta$, NF-kB, TNF- $\alpha$, I- kB and COX-2 in blood of rats, RT-PCR was used. The RNA was removed from the collected blood by the TRIzol method by using kit procedure (Invitrogen ${ }^{\circledR}$ Pure Link RNA). The complementary DNA synthesis was done using protocol of kit manufacturer (K1622: Thermo Scientific $®$, Germany). For quantification and amplification, the kit of SYBR Select Master Mix (Applied Biosystems Thermo Scientific ${ }^{\circledR}$, Germany) was used on qRT-PCR (Applied Biosystems Thermo Scientific ${ }^{\circledR}$, ). The primers were selected from previous study using GAPDH as housekeeping gene (Saleem et al. 2020d).

\section{Assessment of oxidative stress biomarkers}

After 28th day, rats were sacrificed and liver was taken out for estimating superoxide dismutase (SOD), catalase (CAT) activity and malondialdehyde (MDA) level. The $10 \%$ liver homogenate (LH) was prepared (Akhtar et al. 2016). The Lowry's method was used for valuation of protein content in LH (Saleem et al. 2021). The SOD and CAT, and MDA in the LH were estimated by xanthine oxidase, hydrogen peroxide and Thiobarbituric acid (TBA) assays respectively (Bhangale \& Acharya 2016).

\section{Acute toxicity study}

It was performed by following OECD guidelines $425 \mathrm{Up}$ and down procedure with slight changes (Saleem et al. 2020b). The female rats (120-170 g) were distributed in to two groups $(\mathrm{n}=5)$. Briefly, $2000 \mathrm{mg} / \mathrm{kg}$ dose of QLME was given and observed for change in behavior, gait, movements, respiration and mortality at $0.5,1,2$, and $4 \mathrm{hr}$ till 48 th hour. While in NC, only $1 \mathrm{ml} \mathrm{DW}$ was given. The rats were observed for clinical signs of toxicity like mortality, body temperature, respiratory rate and motor movements during this period. The bodyweight was also measured on 1,7 and 14th day.

\section{Statistical analysis}

The results were described as mean \pm standard deviation (S.D) and were inspected by One-way and Twoway analysis of variance (ANOVA) followed by multiple comparison test using GraphPad Prism ${ }^{\circledR}$ software version 7.0. The significance level was considered at $p<0.05$.

\section{Results}

The percentage yield of QLME and QLAQ was 6.1\% and 4.05\% respectively.

\section{Phytochemicals analysis}

It was observed that tannins, phenols, glycosides, terpenoids and flavonoids were present in QLME and QLAQ while alkaloids and carbohydrates were present only in QLAQ. Saponins, proteins and steroids were absent in both extracts. The QLME contained higher amount of phenolic acid and flavonoids (TPC: 201.2 $\pm 0.72 \mathrm{mg} \mathrm{GAE} / \mathrm{g}$ and TFC: $30.30 \pm 0.66 \mathrm{mg} \mathrm{CE} / \mathrm{g}$ ) than QLAQ (TPC: $188.07 \pm 0.50 \mathrm{mg} \mathrm{GAE} / \mathrm{g}$ and TFC: $23.37 \pm 0.85 \mathrm{mg} \mathrm{CE} / \mathrm{g}$ ). 


\section{Quantitative analysis}

The HPLC analysis of QLME revealed that it contained the highest amount of quercetin (265.53 ppm) followed by sinapic acid (73.86 ppm). The QLAQ had the highest amount of p-coumaric acid (255.34 $\mathrm{ppm}$ ) followed by catechin (236.9 ppm). Phenolic acid and flavonoids detected in the plant extracts are presented in Table 1.

Table 1

Phytochemical detected in Quercus leucotrichophora plant extracts by HPLC

\begin{tabular}{|lllll|}
\hline Extracts & Compound Name & Retention time $(\mathrm{min})$ & Area $(\mathrm{mV.s})$ & Amount $(\mathbf{p p m})$ \\
\hline \multirow{2}{*}{ QLME } & Sinapic acid & 12.531 & $1,477,225.2$ & 73.86 \\
\cline { 2 - 5 } & Ferulic acid & 12.764 & $510,806.5$ & 25.28 \\
\cline { 2 - 5 } & Quercetin & 25.020 & $2,795,099.8$ & 265.53 \\
\multirow{2}{*}{ QLAQ } & Catechin & 3.266 & $631,735.9$ & 236.90 \\
\cline { 2 - 5 } & p-coumaric acid & 5.581 & $851,125.6$ & 255.34 \\
\hline
\end{tabular}

In-vitro antioxidant activity

The DPPH assay revealed that both extracts exhibited profound dose dependent antioxidant activity. The highest \% scavenging was presented by $1600 \mu \mathrm{g} / \mathrm{ml}$ solution. The antioxidant activity of QLME (67.64 \pm $0.43 \%)$ and QLAQ $(63.09 \pm 0.65 \%)$ at $1600 \mu \mathrm{g} / \mathrm{ml}$ was significantly $(\mathrm{p}<0.0001)$ different compared to ascorbic acid $(72.75 \pm 0.21 \%)$ as shown in Figure 1

\section{Inhibition of protein denaturation}

The EA and BSA denaturation inhibition assays revealed that both extracts inhibited protein denaturation at all concentrations. In egg albumin assay, the maximum \% inhibition was shown by QLME $(85.42 \pm$ $0.42 \%)$ and QLAQ $(79.44 \pm 0.52 \%)$ at $1600 \mu \mathrm{g} / \mathrm{ml}$ that was significantly different as compared to piroxicam (75.13 $\pm 0.81 \%)$. In BSA assay, the maximum per inhibition exerted by QLME $(87.54 \pm 0.73 \%)$ and QLAQ $(91.74 \pm 0.44 \%)$ at $1600 \mu \mathrm{g} / \mathrm{ml}$ that was considerably different from piroxicam $(84.05 \pm 0.54 \%)$ as displayed in Figure 1.

\section{HRBC membrane stabilization assay}

It was revealed that both extracts dose dependently inhibited the RBC's membrane lysis (Figure 1). The increased \% protection of RBC's membrane lysis by QLME $(66.16 \pm 0.83 \%)$ and QLAQ $(62.17 \pm 0.32 \%)$ at $1600 \mu \mathrm{g} / \mathrm{ml}$ was pointedly different $(p<0.0001)$ in comparison to piroxicam $(58.23 \pm 0.22 \%)$.

\section{Effect on xylene induced ear edema}


There was a considerable increase in ear weight of DC in comparison to NC. The QLME $(91.37 \pm 3.24 \%)$ and QLAQ $(86.42 \pm 2.88 \%)$ significantly $(\mathrm{p}<0.001)$ reduced ear edema at $600 \mathrm{mg} / \mathrm{kg}$ compared to piroxicam (54.94 $\pm 2.31 \%)$ as presented in Figure 2 .

\section{Effect on carrageenan induced paw edema}

The carrageenan administration produced a considerable increase in paw diameter in DC rats as compared to NC. All treated groups showed significant $(p<0.05)$ reduction in paw edema in comparison with $\mathrm{DC}$ at respective time interval (Table 2). The maximum reduction in paw edema exhibited by QLME $(3.59 \pm 0.08 \mathrm{~mm})$ at $600 \mathrm{mg} / \mathrm{kg}$ was notably $(\mathrm{p}<0.0001)$ different as compared to piroxicam $(3.72 \pm 0.49$ $\mathrm{mm})$. The maximum \% inhibition was exhibited by QLME (29.03\%) at $600 \mathrm{mg} / \mathrm{kg}$ as compared to other groups as given in Table 2 .

Table 2

Effect of Quercus leucotrichophora extracts in carrageenan induced paw edema

\begin{tabular}{|c|c|c|c|c|c|}
\hline \multirow[t]{2}{*}{ Hour } & \multirow[t]{2}{*}{ Disease control } & \multirow[t]{2}{*}{ Standard control } & \multicolumn{3}{|l|}{ QLME (mg/kg) } \\
\hline & & & 150 & 300 & 600 \\
\hline \multirow[t]{2}{*}{0} & $3.64 \pm 0.11$ & $3.66 \pm$ & $3.74 \pm 0.09$ & $3.73 \pm$ & $3.57 \pm$ \\
\hline & & 0.05 & & 0.11 & 0.09 \\
\hline \multirow[t]{2}{*}{1} & $4.82 \pm 0.07$ & $4.60 \pm$ & $4.72 \pm 0.15$ & $4.74 \pm 0.15$ & $4.64 \pm 0.12$ \\
\hline & & $0.11(4.49 \%)$ & $(2.01 \%)$ & $(1.52 \%)$ & $(3.67 \%)$ \\
\hline \multirow[t]{2}{*}{2} & $5.84 \pm 0.09$ & $5.31 \pm 0.09 \mathrm{a}^{\mathrm{a}}$ & $5.52 \pm 0.13 a^{a "}$ & $5.41 \pm 0.22^{a}$ & $5.25 \pm 0.13^{a}$ \\
\hline & & $(9.02 \%)$ & $(5.42 \%)$ & $(7.31 \%)$ & $(10.05 \%)$ \\
\hline \multirow[t]{2}{*}{3} & $5.87 \pm 0.09$ & $5.14 \pm 0.21^{a}$ & $5.33 \pm 0.13^{a}$ & $5.19 \pm 0.16^{a}$ & $4.99 \pm 0.11^{a}$ \\
\hline & & (12.49\%) & (9.25\%) & $(11.69 \%)$ & (15.04\%) \\
\hline \multirow[t]{2}{*}{4} & $5.45 \pm 0.43$ & $4.61 \pm 0.16^{a}$ & $4.79 \pm 0.24^{a}$ & $4.68 \pm 0.09$ a & $4.45 \pm 0.08^{a}$ \\
\hline & & (15.47\%) & (12.17\%) & $(14.13 \%)$ & (18.29\%) \\
\hline \multirow[t]{2}{*}{5} & $5.32 \pm 0.46$ & $4.36 \pm 0.19^{a}$ & $4.52 \pm 0.26^{a}$ & $4.39 \pm 0.11^{a}$ & $4.14 \pm 0.07^{a}$ \\
\hline & & (18.05\%) & $(15.10 \%)$ & $(17.48 \%)$ & $(22.12 \%)$ \\
\hline \multirow[t]{2}{*}{6} & $5.25 \pm 0.42$ & $4.07 \pm 0.13^{a}$ & $4.33 \pm 0.26^{a c^{\prime}}$ & $4.06 \pm 0.05^{a}$ & $3.88 \pm 0.05^{a}$ \\
\hline & & $(22.49 \%)$ & (17.47\%) & (22.49\%) & $(26.05 \%)$ \\
\hline \multirow[t]{2}{*}{8} & $5.06 \pm 0.54$ & $3.72 \pm 0.09^{a}$ & $4.03 \pm 0.10 \mathrm{ac}^{\prime \prime}$ & $3.81 \pm 0.09 a^{a}$ & $3.59 \pm 0.08^{a}$ \\
\hline & & $(26.53 \%)$ & $(20.41 \%)$ & (24.75\%) & $(29.03 \%)$ \\
\hline
\end{tabular}


Results as presented mean \pm S.D. $(n=6)$; Two-way ANOVA; Tukey's test; a", a"', a: $p<0.01,0.001$ and 0.0001; 'b' in contrast to NC and c', c', c'”, c: p< 0.05, 0.01, 0.001 and 0.0001 to Standard control.

\section{Effect on paw diameter of arthritic rats}

The anti-arthritic effect of QLME was evaluated against CFA induced arthritis in rats. On 8th day, there was a considerable rise in paw diameter in all arthritic rats in contrast to NC. A substantial increase in paw diameter in DC rats was noted until the 28th day compared to NC. The QLME $600 \mathrm{mg} / \mathrm{kg}(4.05 \pm$ $0.07 \mathrm{~mm})$ considerably $(p<0.05)$ reduced paw edema along with MTX treated rats $(3.92 \pm 0.16 \mathrm{~mm})$ from 16 to 28 th day. The maximum \% inhibition was exhibited by MTX (50.02\%) followed by QLME 600 $\mathrm{mg} / \mathrm{kg} /$ day treated rats $(48.34 \%)$ at 28th day. The inhibitory effect of QLME $600 \mathrm{mg} / \mathrm{kg}$ on paw edema was insignificantly varied from MTX on 16 to 28th (Table 3 ).

Table 3

Effect of Quercus leucotrichophora extract on paw diameter in CFA induced arthritis

\begin{tabular}{|c|c|c|c|c|c|c|}
\hline \multirow[t]{2}{*}{ Days } & \multirow{2}{*}{$\begin{array}{l}\text { Normal } \\
\text { control }\end{array}$} & \multirow{2}{*}{$\begin{array}{l}\text { Disease } \\
\text { control }\end{array}$} & \multirow{2}{*}{$\begin{array}{l}\text { Standard } \\
\text { control }\end{array}$} & \multicolumn{3}{|l|}{ QLME (mg/kg) } \\
\hline & & & & 150 & 300 & 600 \\
\hline 1 & $3.85 \pm 0.13$ & $3.82 \pm 0.17$ & $3.86 \pm 0.13$ & $3.78 \pm 0.10$ & $3.79 \pm 0.12$ & $3.83 \pm 0.13$ \\
\hline 8 & $\begin{array}{l}3.90 \pm 0.10 \\
\text { a }\end{array}$ & $6.85 \pm 0.11$ & $6.73 \pm 0.58$ & $6.71 \pm 0.09$ & $6.64 \pm 0.27$ & $6.74 \pm 0.32$ \\
\hline 12 & $\begin{array}{l}3.92 \pm 0.10 \\
\text { a }\end{array}$ & $7.11 \pm 0.18$ & $\begin{array}{l}6.47 \pm 0.26 \\
(9.01 \%)\end{array}$ & $\begin{array}{l}6.73 \pm 0.12 \\
(5.33 \%)\end{array}$ & $\begin{array}{l}6.47 \pm 0.53 \\
(8.99 \%)\end{array}$ & $\begin{array}{l}6.53 \pm 0.35 \\
(8.15 \%)\end{array}$ \\
\hline 16 & $\begin{array}{l}3.94 \pm 0.10 \\
\text { a }\end{array}$ & $7.94 \pm 0.04$ & $\begin{array}{l}5.70 \pm 0.59^{a} \\
(28.16 \%)\end{array}$ & $\begin{array}{l}6.40 \pm 0.29 \mathrm{ac}^{\prime \prime} \\
(19.44 \%)\end{array}$ & $\begin{array}{l}6.18 \pm 0.47^{a} \\
(22.16 \%)\end{array}$ & $\begin{array}{l}5.62 \pm 0.35^{a} \\
(29.22 \%)\end{array}$ \\
\hline 20 & $\begin{array}{l}3.95 \pm 0.09 \\
\text { a }\end{array}$ & $8.31 \pm 0.18$ & $\begin{array}{l}5.33 \pm 0.42^{a} \\
(35.77 \%)\end{array}$ & $\begin{array}{l}6.08 \pm 0.19 \mathrm{ac}^{\prime \prime} \\
(26.79 \%)\end{array}$ & $\begin{array}{l}5.71 \pm 0.42^{a} \\
(31.25 \%)\end{array}$ & $\begin{array}{l}5.14 \pm 0.188^{a} \\
(38.08 \%)\end{array}$ \\
\hline 24 & $\begin{array}{l}3.97 \pm 0.08 \\
\text { a }\end{array}$ & $7.88 \pm 0.42$ & $\begin{array}{l}4.65 \pm 0.22^{a} \\
(41.04 \%)\end{array}$ & $\begin{array}{l}5.43 \pm 0.18^{a c^{\prime \prime}} \\
(31.05 \%)\end{array}$ & $\begin{array}{l}5.11 \pm 0.36^{a} \\
(35.19 \%)\end{array}$ & $\begin{array}{l}4.48 \pm 0.16^{a} \\
(43.12 \%)\end{array}$ \\
\hline 28 & $\begin{array}{l}4.04 \pm 0.08 \\
a\end{array}$ & $7.84 \pm 0.28$ & $\begin{array}{l}3.92 \pm 0.16^{a} \\
(50.02 \%)\end{array}$ & $\begin{array}{l}4.93 \pm 0.21^{\mathrm{ac}} \\
(37.08 \%)\end{array}$ & $\begin{array}{l}4.67 \pm 0.26{ }^{a c} \\
(40.43 \%)\end{array}$ & $\begin{array}{l}4.05 \pm 0.07^{a} \\
(48.34 \%)\end{array}$ \\
\hline
\end{tabular}

Results as mean \pm S.D. $(n=6)$; Two-way ANOVA, Tukey's test; ' $a$ ' ( $p<0.0001)$ in contrast to DC and c", $c$ '”' and $c$ : $p<0.01,0.001,0.0001$ to SC.

\section{Effect on body weight}


There was a significant decline in body weight after CFA inoculation in all groups compared to NC at 8th day. The fall in weight was continuous in DC from the 8th day as compared to NC till the end of the study. However, treatment with QLME $(150-600 \mathrm{mg} / \mathrm{kg})$ and MTX caused a significant $(p<0.05)$ restoration of body weight from 16 to 28th day compared to DC. The MTX $(178.4 \pm 3.65 \mathrm{~g})$ and QLME $600 \mathrm{mg} / \mathrm{kg} / \mathrm{day}$ $(175.3 \pm 5.19 \mathrm{~g})$ treated rats exhibited considerable $(p<0.05)$ restoration in body weight on the 28th day, in contrast to DC while the effect of QLME $600 \mathrm{mg} / \mathrm{kg} /$ day on body weight was insignificantly varied from MTX on respective day as given in Table 4 .

Table 4

Effect of Quercus leucotrichophora on body weight (g)

\begin{tabular}{|c|c|c|c|c|c|c|}
\hline \multirow[t]{2}{*}{ Days } & \multirow{2}{*}{$\begin{array}{l}\text { Normal } \\
\text { Control }\end{array}$} & \multirow{2}{*}{$\begin{array}{l}\text { Disease } \\
\text { control }\end{array}$} & \multirow{2}{*}{$\begin{array}{l}\text { Standard } \\
\text { control }\end{array}$} & \multicolumn{3}{|l|}{ QLME (mg/kg) } \\
\hline & & & & 150 & 300 & 600 \\
\hline \multirow[t]{2}{*}{1} & \multirow[t]{2}{*}{$160.8 \pm 1.92$} & $160.5 \pm$ & \multirow[t]{2}{*}{$160.8 \pm 2.59$} & \multirow[t]{2}{*}{$161.3 \pm 1.53$} & \multirow[t]{2}{*}{$160.3 \pm 4.16$} & \multirow{2}{*}{$\begin{array}{l}161.5 \\
\pm 4.51\end{array}$} \\
\hline & & 2.65 & & & & \\
\hline \multirow[t]{2}{*}{8} & \multirow{2}{*}{$\begin{array}{l}170.8 \pm 1.79 \\
\text { a }\end{array}$} & $146.5 \pm$ & \multirow[t]{2}{*}{$145.6 \pm 2.19$} & \multirow[t]{2}{*}{$144.3 \pm 3.51$} & \multirow[t]{2}{*}{$146.3 \pm 2.52$} & \multirow{2}{*}{$\begin{array}{l}145.3 \\
\pm 4.03\end{array}$} \\
\hline & & 2.38 & & & & \\
\hline \multirow[t]{2}{*}{12} & \multirow{2}{*}{$\begin{array}{l}173.1 \pm 1.58 \\
\text { a }\end{array}$} & $141.5 \pm$ & \multirow[t]{2}{*}{$147.2 \pm 1.92$} & \multirow[t]{2}{*}{$143.3 \pm 1.53$} & \multirow[t]{2}{*}{$147.7 \pm 4.16$} & \multirow[t]{2}{*}{$149.3 \pm 3.86$} \\
\hline & & 2.38 & & & & \\
\hline \multirow[t]{2}{*}{16} & \multirow{2}{*}{$\begin{array}{l}174.6 \pm 1.14 \\
\text { a }\end{array}$} & $137.8 \pm$ & \multirow{2}{*}{$162.4 \pm 3.51^{\mathrm{a}}$} & \multirow{2}{*}{$151.7 \pm 3.21^{\mathrm{ac}}$} & \multirow{2}{*}{$\begin{array}{l}154.0 \pm 5.57 \\
\text { ac' }^{\prime}\end{array}$} & \multirow{2}{*}{$\begin{array}{l}159.0 \pm 7.53 \\
\text { a }\end{array}$} \\
\hline & & 2.22 & & & & \\
\hline \multirow[t]{2}{*}{20} & \multirow{2}{*}{$\begin{array}{l}178.2 \pm 1.92 \\
\text { a }\end{array}$} & $134.8 \pm$ & \multirow[t]{2}{*}{$169.2 \pm 4.21^{a}$} & \multirow[t]{2}{*}{$155.0 \pm 2.0^{\mathrm{ac}}$} & \multirow{2}{*}{$\begin{array}{l}159.0 \pm 5.0 \\
\mathrm{ac}^{\prime \prime}\end{array}$} & \multirow{2}{*}{$\begin{array}{l}164.0 \pm 7.87 \\
\text { a }\end{array}$} \\
\hline & & 1.71 & & & & \\
\hline \multirow[t]{2}{*}{24} & \multirow{2}{*}{$\begin{array}{l}182.6 \pm 1.67 \\
\text { a }\end{array}$} & $138.0 \pm$ & \multirow[t]{2}{*}{$174.6 \pm 3.05^{a}$} & $160 \pm 2.65^{\mathrm{ac}}$ & $164.0 \pm 4.58$ & $169.3 \pm 6.95$ \\
\hline & & 2.16 & & & & \\
\hline 28 & $\begin{array}{l}185.8 \pm 1.92 \\
\text { a }\end{array}$ & $141.3 \pm 1.89$ & $178.4 \pm 3.65^{\mathrm{a}}$ & $164.3 \pm 1.53^{\mathrm{ac}}$ & $\begin{array}{l}167.3 \pm 4.51 \\
\text { ac" }\end{array}$ & $\begin{array}{l}175.3 \pm 5.19 \\
\text { a }\end{array}$ \\
\hline
\end{tabular}

Results as mean \pm S.D. $(n=6)$; Two-way ANOVA; Tukey's test; ' $a$ ': $p<0.0001$ to Disease control and c', c', $c^{\prime \prime \prime}$ and c: $p<0.05,0.01,0.001,0.0001$ to Standard control.

\section{Effect on arthritic index}

During whole study, the DC showed continuous increase in arthritic index. The treatment groups exhibited substantial $(p<0.05)$ restoration of the arthritic index from day 16 till the end of the study. The maximum arthritic index was observed in DC at 28th day $(4.25 \pm 0.96)$. The plant extract exerted the most pronounced effect on the 28th (Figure 3). 


\section{Effect on blood parameters}

There was a remarkable $(\mathrm{p}<0.0001)$ decrease in the level of hemoglobin $(\mathrm{Hb})$ and RBC's in DC as compared to NC (Figure 4 and 5). However, there was a significant $(p<0.05)$ rise in platelets, c-reactive protein (CRP), erythrocyte sedimentation rate (ESR), RF and total leukocyte counts (TLC) in DC in comparison to NC. All the treatment groups at $150-600 \mathrm{mg} / \mathrm{kg}$ restored the hematological parameters in arthritic rats as shown in Figure 4 and 5.

There were non-significant changes by induction of arthritis on urea and creatinine in arthritic rats. The levels of ALT, ALP and AST were considerably $(p<0.05)$ higher in DC as compared to NC, and all the treatment groups significantly reduced their level in arthritic rats (Figure 5).

\section{Effect on weight of spleen and thymus}

The weight of the spleen and thymus increased in DC than NC. The weight of spleen and thymus was significantly $(p<0.05)$ restored by QLME (spleen: $0.45 \pm 0.03$ g; thymus: $0.23 \pm 0.02 \mathrm{~g}$ ) at $600 \mathrm{mg} / \mathrm{kg}$ and MTX (spleen: $0.42 \pm 0.01 \mathrm{~g}$; thymus: $0.20 \pm 0.02 \mathrm{~g}$ ) treated groups in contrast to DC as shown in Figure 6 .

\section{Effect on expression of genes}

The expressions of multiple inflammatory biomarkers were quantified by qRT-PCR in all rats after 28 days of CFA inoculation. It was observed that there was a remarkable $(p<0.05)$ down-regulation of IL-10 (36.87 $\pm 2.23 \%), \mathrm{IL}-4(45.03 \pm 1.30 \%)$ and $\mathrm{I}-\mathrm{kBa}(46.17 \pm 1.86 \%)$ along with upregulation of NF-kB $(4.67 \pm 0.40)$; COX-2 (6.23 \pm 0.30$)$; IL-6 (6.03 \pm 0.42$)$; TNF-a (4.97 \pm 0.31$)$ and IL-1 $\beta(4.17 \pm 0.31$ fold change) in DC as compared to NC. The level of these biomarkers was restored in all treatment groups in contrast to DC (Figure 7). Though, the treatment with MTX (IL-10: $95.67 \pm 2.52$; IL-4: $94.67 \pm 3.01$; I-kBa: $93.33 \pm 2.52 \%$ ) and QLME (IL-10: $90.67 \pm 2.52$; IL-4: $85.33 \pm 1.53$; I-kBa: $93.33 \pm 2.52 \%)$ at $600 \mathrm{mg} / \mathrm{kg} / \mathrm{day}$ had significantly $(p<0.0001)$ increased the expression of these genes in comparison to DC. Moreover, the expressions of IL-6, IL-1 $\beta$, NF-KB, TNF-a, and COX-2 were significantly reduced by QLME (NF-kB: $1.71 \pm$ 0.20; COX-2: $1.72 \pm 0.19$; IL-6: $1.66 \pm 0.09$; TNF-a: $1.62 \pm 0.29$ and IL-1 $\beta$ : $1.67 \pm 0.20$-fold change) at 600 $\mathrm{mg} / \mathrm{kg}$ and MTX (NF-kB: $1.48 \pm 0.15$; COX-2: $1.45 \pm 0.06$; IL-6: $1.52 \pm 0.09$; TNF-a: $1.34 \pm 0.14$ and IL-1 $\beta$ : $1.47 \pm 0.12$-fold change) treated rats in contrast to $\mathrm{DC}$ as given in Figure 7 .

\section{Effect on oxidative stress biomarker}

The oxidative stress was developed after CFA immunization in all rats that was restored with extract at all tested dosage and MTX treated rats (Figure 8). The activities of CAT and SOD were significantly $(p<0.05)$ lowered in DC than NC. There was also an increased level of MDA in LH of DC as compared to NC. All the treatment significantly $(p<0.05)$ improved the activities of CAT and SOD as well as reduced the level of MDA in arthritic rats as compared to DC. The QLME $600 \mathrm{mg} / \mathrm{kg}$ (CAT: $22.64 \pm 0.35$; SOD: $15.08 \pm 0.34$ $\mathrm{U} / \mathrm{mg}$ of protein and MDA: $7.26 \pm 0.12 \mu \mathrm{M} / \mathrm{mg}$ protein) and MTX (CAT: $24.89 \pm 0.25$; SOD: $16.17 \pm 0.11$ $\mathrm{U} / \mathrm{mg}$ of protein and MDA: $7.61 \pm 0.40 \mu \mathrm{M} / \mathrm{mg}$ protein) treated groups significantly $(\mathrm{P}<0.0001)$ restored the levels of oxidative stress biomarkers in contrast to DC as shown in Figure 8. 


\section{Effect on joint histopathology}

At the end of 28th day, the histopathology of ankle joints showed the formation of pannus, inflammation, bone erosion and mononuclear cell infiltration in DC (Figure 10). Furthermore, NC rats were devoid of bone erosion and inflammation (Figure 10). The treatment with QLME (150, 300, $600 \mathrm{mg} / \mathrm{kg}$ ) and MTX profoundly reduced inflammation, pannus formation, bone erosion and cellular infiltration in arthritic groups in comparison to DC as exhibited in Figure $10 c$, $d$, e and $f$.

\section{Acute toxicity study}

After QLME 2000mg/kg administration, the marked changes in behavioral and physiological parameters were not observed. The QLME LD 50 was more than $2000 \mathrm{mg} / \mathrm{kg}$ as no mortality was noticed within 14 days of extracts administration. There were non-significant $(p>0.05)$ changes in body weight of the treated group $(140.3 \pm 1.53 \mathrm{~g})$ as compared to NC $(139.3 \pm 2.52 \mathrm{~g})$ at 14 th day.

\section{Discussion}

The purpose of the current study was to assess the anti-inflammatory and anti-arthritic potential of QL. The QLME extract showing notable anti-oxidant and anti-inflammatory activities were further evaluated in animals by using CFA induced arthritis.

The excessive production of free radicals causes oxidative stress, a hallmark of numerous diseases like arthritis. The medicinal plants containing anti-oxidants reduce the intensity of disease associated with oxidative stress in human. The QLME and QLAQ exhibited prominent anti-oxidant activity probably due to occurrence of high amounts of TFC and TPC. The flavonoids and phenols having high amount of hydroxyl group in plant reduced free radicals and halted oxidative stress as previously described (Arulselvan et al. 2016). The QLME was safe in acute toxicity study as it did not cause mortality and LD $_{50}$ was more than $2000 \mathrm{mg} / \mathrm{kg}$.

The phytochemicals like quercetin, sinapic acid, p-coumaric acid etc. protected lysosomal degradation via free radical scavenging activity (Oyeleke et al. 2018). The denaturation of protein leads to RA by the production of autoantibodies at the target site. It occurred in the presence of strong stimulus like heat, resulting in loss of the structure of protein (Akhtar 2020). Therefore, it can be assumed that the QLME showed the maximum inhibition of protein denaturation and HRBC membrane stabilization than QLAQ due to the presence of higher amount of flavonoids and phenols as detected by HPLC analysis. It has been reported in previous studies that plants containing phenolic compounds like ferulic, p-coumaric, sinapic acid, quercetin and catechin have anti-oxidant and anti-inflammatory activities (Roychoudhury et al. 2021).

Quercetin, a natural flavonoid has improved inflammation and cartilage damage, suggesting its usefulness in RA. It was also reported that quercetin had inhibited neutrophil infiltration in in-vitro and invivo studies (Wang et al. 2021). 
The xylene and carrageenan are considered as acute models of inflammation. The xylene is partially involved in Substance-P release, causing neurogenic inflammation with swelling leading to release of kinins and histamine. The QLME reduced ear inflammation more than QLAQ and its activity was comparable to piroxicam. The similar finding was reported previously by other Quercus species (Shabbir et al. 2018). Carrageenan induced inflammation by its actions on complement system or via mediators of inflammation like histamine, prostaglandins (PG's) and 5-HT. In current findings, carrageenan significantly reduced paw edema by the inhibition of release of inflammatory mediators like PG's, serotonin and histamine by the activated immune cells. The comparison with DC group revealed that QLME had shown profound anti-inflammatory activity followed by QLAQ (Peerzada et al. 2020).

The sinapic acid is derived from cinnamic acid that showed its anti-oxidant, anti-inflammatory, anxiolytic and anti-cancer activities (Bin Jardan et al. 2020). Catechin, a polyphenol exhibited anti-inflammatory, antioxidant and anti-hypertensive actions along with other various health benefits (Lee et al. 2020). Sinapic acid, ferulic acid, quercetin, and catechin detected in QLME and QLAQ might be responsible for in vitro and in vivo anti-inflammatory potential as reported in previous studies (Shabbir et al. 2018).

The CFA was used promisingly to induce polyarthritis in rodents. The CFA suspension contains Mycobacterium tuberculosis killed by heat in un-metabolized oils that is favorably used for induction of polyarthritis in rodents similar in pathogenesis and symptoms to RA in human (Saleem et al. 2020). It caused arthritis in two phases. In the primary phase, inflammation occurred with the release of PGs, whereas secondary immunological phase resulted in the production of auto-antibodies. It leads to accumulation of mononuclear and polynuclear cells in joints which results in structural changes in joint and cartilage via changes in cytokines (TNF-a, IL-6 and IL-1 3 ), chemokines, tissue destructive enzymes (proteases and lysosomes) and anti-oxidant enzymes (Thite, Patil, \& Naik, 2014). In the current study, CFA immunization caused notable paw edema and weight loss in DC which was restored with plant extract dose dependently as evidenced from arthritic indices and histological findings.

The TNF- $a$ is accountable for joint destruction and synovial infiltration in RA. It causes the formation of other pro-inflammatory cytokines. The IL-1 $\beta$ is responsible for morning stiffness and bone erosion in RA. The increased levels of CRP, anemia and reduced levels of albumin are also due to increased levels of IL- 6 that leads myocardial infarction, and an extra-articular manifestation of RA (Hashizume \& Mihara 2011). The expression of pro-inflammatory cytokines (IL-6, IL-1 $\beta$, NF-KB, COX-2 and TNF-a) were reduced with treatment at all dosage levels as evidenced from the improvement in blood parameters of arthritic rats also.

IL-4 is involved in Th2 cell production. The IL-4 and IL-10 halt pro-inflammatory cytokine release from monocytes as well as synovial fibroblasts and their level was reduced in RA patients as also obvious in DC animals in the current study (Mateen et al. 2016). The levels of anti-inflammatory cytokines were increased in treated rats as co-evidenced from the reduction of paw inflammation.

As reported in previous studies, quercetin caused an inhibition of late phase inflammation by the inhibition of TNF-a, lipoxygenase, COX-2 and phospholipase A2 (Yin et al. 2019). The QLME at 600 
$\mathrm{mg} / \mathrm{kg} /$ day showed profound anti-arthritic activity comparable to MTX treated group. The presence of quercetin, sinapic acid, ferulic acid, and other phenolic and flavonoids in QLME might be responsible for its anti-arthritic potential by downregulating pro-inflammatory and upregulating anti-inflammatory cytokines in treated rats (Foyet et al. 2015).

The systemic biomarkers of arthritis like RF, CRP, ESR, HB, RBCs, WBCs and platelets were notably altered in arthritic rats that were restored by treatment (Shabbir et al. 2018). Enhanced ROS generation occurred because of increased discharge of inflammatory cytokines from activated immune cells like neutrophils and macrophages ultimately headed to synovium cellular infiltration (Ishibashi 2013). In the current study, oxidative stress was reduced in treated arthritic rats in contrast to DC. Numerous other species of Quercus genus such as Q. dilatata, Q. incana, Q. sideroxyla, Q. durifolia, and Q. eduardii and Q. macrocarpa have exhibited anti-inflammatory, anti-oxidant and anti-bacterial activities (Moreno-Jimenez et al. 2015; Taib et al. 2020);(Burlacu et al. 2020).

\section{Conclusion}

It was concluded that QL exhibited in-vitro anti-oxidant and anti-inflammatory activity along with in-vivo anti-arthritic activity in Wistar rats might be due to the presence of Ferulic acid, sinapic acid, catechin and quercetin as detected with HPLC. QLME exhibited anti-arthritic potential by restoring paw edema, body and immune organ weight. Additionally, QLME reinstated altered blood parameters, pro-, antiinflammatory and oxidative stress biomarkers in treated rats. Current findings suggested the QL leaves for the treatment of inflammation and arthritis. There is an immense need for activity guided fractionation of QLME to isolate anti-arthritic component. Moreover, there should be detailed toxicity study of QLME to assure its safety for human use.

\section{Declarations}

\section{Acknowledgments}

This research work was not funded by any public or private sector funding agency.

\section{Compliance with ethical standards}

\section{Conflict of interest}

The authors declare that they have no conflict of interest.

\section{Data availability statement}

Authors declare that all the data supporting the findings of this study are included in the article.

\section{References}


1. Akhtar MF (2020) HPLC analysis and pharmacological study of Quercus dilatata Lindle. ex Royle aqueous methanolic extract in Sprague Dawley rats. Pakistan Journal of Pharmaceutical Sciences

2. Akhtar MF, Ashraf M, Anjum AA, Javeed A, Sharif A, Saleem A, Akhtar B (2016) Textile industrial effluent induces mutagenicity and oxidative DNA damage and exploits oxidative stress biomarkers in rats. Environ Toxicol Pharmacol 41:180-186

3. Arulselvan P, Tan WS, Gothai S, Muniandy K, Fakurazi S, Esa NM, Alarfaj AA, Kumar SS (2016) Antiinflammatory potential of ethyl acetate fraction of Moringa oleifera in downregulating the NF-KB signaling pathway in lipopolysaccharide-stimulated macrophages. Molecules 21:1452

4. Asif M, Saadullah M, Yaseen HS, Saleem M, Yousaf HM, Khan IU, Yaseen M, Shams MU (2020) Evaluation of in vivo anti-inflammatory and anti-angiogenic attributes of methanolic extract of Launaea spinosa.Inflammopharmacology,1-16

5. Bhangale JO, Acharya SR (2016) Anti-Parkinson activity of petroleum ether extract of Ficus religiosa (L.) leaves. Advances in pharmacological sciences 2016

6. Bin Jardan YA, Ansari MA, Raish M, Alkharfy KM, Ahad A, Al-Jenoobi Fl, Haq N, Khan MR, Ahmad A (2020) Sinapic Acid Ameliorates Oxidative Stress, Inflammation, and Apoptosis in Acute DoxorubicinInduced Cardiotoxicity via the NF- KB-Mediated Pathway. BioMed research international 2020, 3921796.

7. Burlacu E, Nisca A, Tanase C (2020) A comprehensive review of phytochemistry and biological activities of Quercus species. Forests 11:904

8. Cheruth AJ, Al Naqbi KM, El-Kaabi AAA, Odeh OW, Kandhan K, Maqsood S, Kurup SS, Sakkir S (2016) In vitro antioxidant activities and screening of phytochemicals from methanolic and ethyl acetate extracts of Calligonum comosum L'Her. Oriental Pharmacy and Experimental Medicine 16:209-215

9. Firestein GS (2003) Evolving concepts of rheumatoid arthritis. Nature 423:356-361

10. Foyet HS, Tsala DE, Bodo JZE, Carine AN, Heroyne LT, Oben EK (2015) Anti-inflammatory and antiarthritic activity of a methanol extract from Vitellaria paradoxa stem bark. Pharmacognosy research 7:367

11. Han X, Su D, Xian X, Zhou M, Li X, Huang J, Wang J, Gao H (2016) Inhibitory effects of Saussurea involucrata (Kar. et Kir.) Sch.-Bip. on adjuvant arthritis in rats. J Ethnopharmacol 194:228-235

12. Harrison MAA, Wise RM, Benjamin BP, Hochreiner EM, Mohiuddin OA, Bunnell BA (2021) AdiposeDerived Stem Cells from Obese Donors Polarize Macrophages and Microglia toward a ProInflammatory Phenotype. Cells 10:26

13. Hashizume M, Mihara M (2011) The roles of interleukin-6 in the pathogenesis of rheumatoid arthritis. Arthritis 2011

14. Ishibashi T (2013) Molecular hydrogen: new antioxidant and anti-inflammatory therapy for rheumatoid arthritis and related diseases. Curr Pharm Design 19:6375-6381

15. Lee HA, Song YR, Park MH, Chung HY, Na HS, Chung J (2020) Catechin ameliorates Porphyromonas gingivalis-induced inflammation via the regulation of TLR2/4 and inflammasome signaling. $J$ Periodontol 91:661-670 
16. Mateen S, Zafar A, Moin S, Khan AQ, Zubair S (2016) Understanding the role of cytokines in the pathogenesis of rheumatoid arthritis. Clin Chim Acta 455:161-171

17. Moreno-Jimenez MR, Trujillo-Esquivel F, Gallegos-Corona MA, Reynoso-Camacho R, González-Laredo RF, Gallegos-Infante JA, Rocha-Guzmán NE, Ramos-Gomez M (2015) Antioxidant, anti-inflammatory and anticarcinogenic activities of edible red oak (Quercus spp.) infusions in rat colon carcinogenesis induced by 1, 2-dimethylhydrazine. Food Chem Toxicol 80:144-153

18. Oliver JE, Silman AJ (2006) Risk factors for the development of rheumatoid arthritis. Scand J Rheumatol 35:169-174

19. Oyeleke SA, Ajayi AM, Umukoro S, Aderibigbe A, Ademowo OG (2018) Anti-inflammatory activity of Theobroma cacao L. stem bark ethanol extract and its fractions in experimental models. $J$ Ethnopharmacol 222:239-248

20. Peerzada S, Khan MT, Akhtar MF, Saleem A, Hamid I, Akhtar B, Ali S, Ahmed S, Raza M (2020) Phytochemical, anti-inflammatory, anti-nociceptive and cytotoxic basis for the use of Haloxylon stocksii. Pak J Pharm Sci 33:887-894

21. Placha D, Jampilek J (2021) Chronic Inflammatory Diseases, Anti-Inflammatory Agents and Their Delivery Nanosystems. Pharmaceutics 13:64

22. Roychoudhury S, Sinha B, Choudhury BP, Jha NK, Palit P, Kundu S, Mandal SC, Kolesarova A, Yousef MI, Ruokolainen J, Slama P, Kesari KK (2021) Scavenging Properties of Plant-Derived Natural Biomolecule Para-Coumaric Acid in the Prevention of Oxidative Stress-Induced Diseases. Antioxidants 10:1205

23. Saleem A, Saleem M, Akhtar MF (2020a) Antioxidant, anti-inflammatory and antiarthritic potential of Moringa oleifera Lam: An ethnomedicinal plant of Moringaceae family. South African Journal of Botany 128:246-256

24. Saleem A, Saleem M, Akhtar MF, Ashraf Baig MMF, Rasul A (2020b) HPLC analysis, cytotoxicity, and safety study of Moringa oleifera Lam.(wild type) leaf extract. J Food Biochem 44:e13400

25. Saleem A, Saleem M, Akhtar MF, Shahzad M, Jahan S (2020c) Moringa rivae leaf extracts attenuate Complete Freund's adjuvant-induced arthritis in Wistar rats via modulation of inflammatory and oxidative stress biomarkers. Inflammopharmacology 28:139-151

26. Saleem A, Saleem M, Akhtar MF, Shahzad M, Jahan S (2020d) Polystichum braunii extracts inhibit Complete Freund's adjuvant-induced arthritis via upregulation of I-KB, IL-4, and IL-10, downregulation of COX-2, PGE2, IL-1 $\beta$, IL-6, NF-KB, and TNF- $\alpha$, and subsiding oxidative stress. Inflammopharmacology 28:1633-1648

27. Saleem A, Saleem M, Akhtar MF, Sharif A, Javaid Z, Sohail K (2019) In vitro and in vivo anti-arthritic evaluation of Polystichum braunii to validate its folkloric claim. Pakistan Journal of Pharmaceutical Sciences32

28. Saleem U, Akhtar R, Anwar F, Shah MA, Chaudary Z, Ayaz M, Ahmad B (2021) Neuroprotective potential of Malva neglecta is mediated via down-regulation of cholinesterase and modulation of oxidative stress markers. Metab Brain Dis 36:889-900 
29. Semwal P, Painuli S, Badoni H, Bacheti RK (2018) Screening of phytoconstituents and antibacterial activity of leaves and bark of Quercus leucotrichophora A. Camus from Uttarakhand Himalaya. Clinical Phytoscience 4:1-6

30. Shabbir A, Batool SA, Basheer MI, Shahzad M, Sultana K, Tareen RB, Iqbal J (2018) Ziziphora clinopodioides ameliorated rheumatoid arthritis and inflammatory paw edema in different models of acute and chronic inflammation. Biomed Pharmacother 97:1710-1721Saeed ul H

31. Singh A, Bisht M (2018) Evaluation of in-vitro antioxidant potential and in-vivo hepatoprotective activity of root extract of Quercus oblongata D. DON. Journal of Drug Delivery and Therapeutics 8:152-161

32. Stankov SV (2012) Definition of inflammation, causes of inflammation and possible antiinflammatory strategies. The open inflammation journal 5:1-9

33. Taib M, Rezzak Y, Bouyazza L, Lyoussi B (2020) Medicinal uses, phytochemistry, and pharmacological activities of Quercus Species. Evidence-Based Complementary and Alternative Medicine 2020

34. Wang Y, Chen S, Du K, Liang C, Wang S, Owusu Boadi E, Li J, Pang X, He J, Chang Y (2021) -x. Traditional herbal medicine: Therapeutic potential in rheumatoid arthritis. Journal of Ethnopharmacology 279, 114368

35. Yin J, Kim HH, Hwang IH, Kim DH, Lee MW (2019) Anti-inflammatory effects of phenolic compounds isolated from Quercus mongolica Fisch. ex Ledeb. on UVB-irradiated human skin cells. Molecules 24:3094

36. Zhang C (2021) Flare-up of cytokines in rheumatoid arthritis and their role in triggering depression: Shared common function and their possible applications in treatment. Biomedical Reports 14:1

\section{Figures}



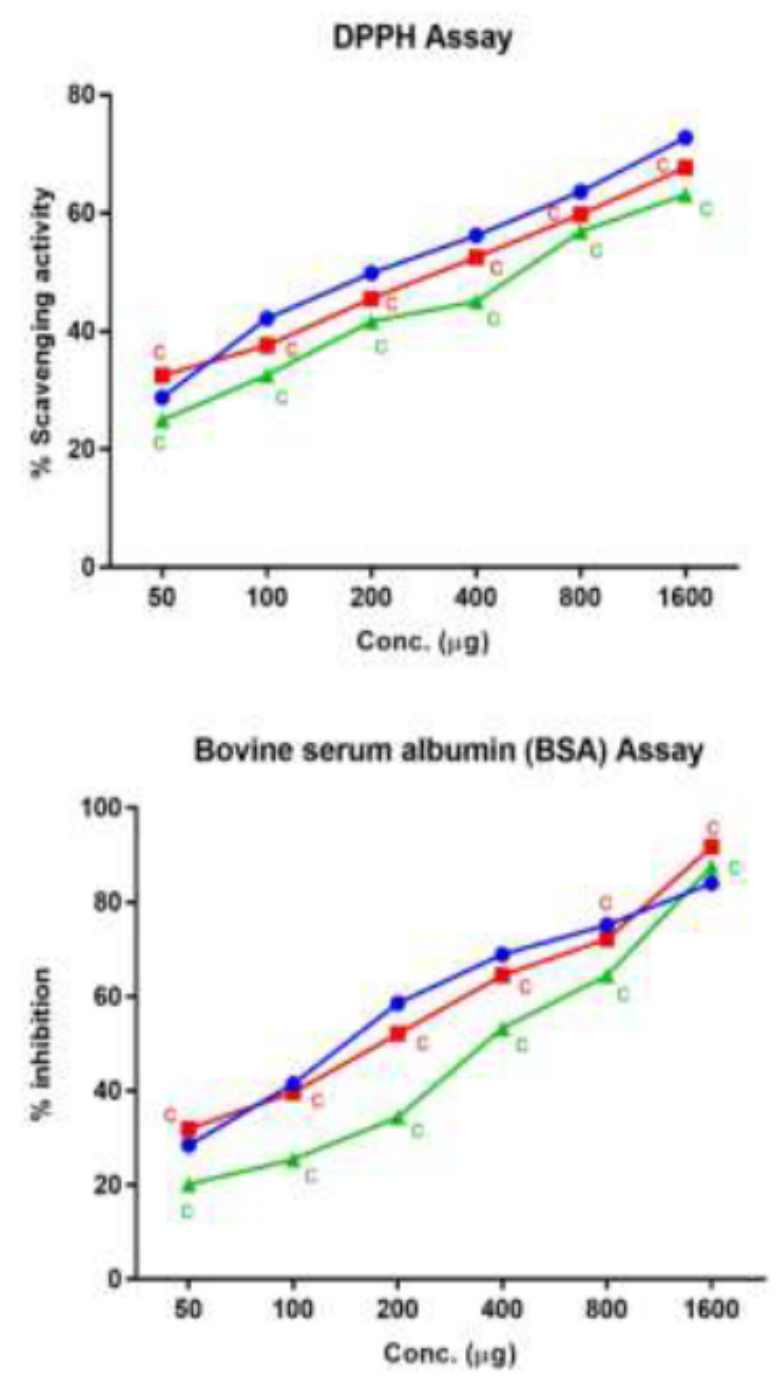
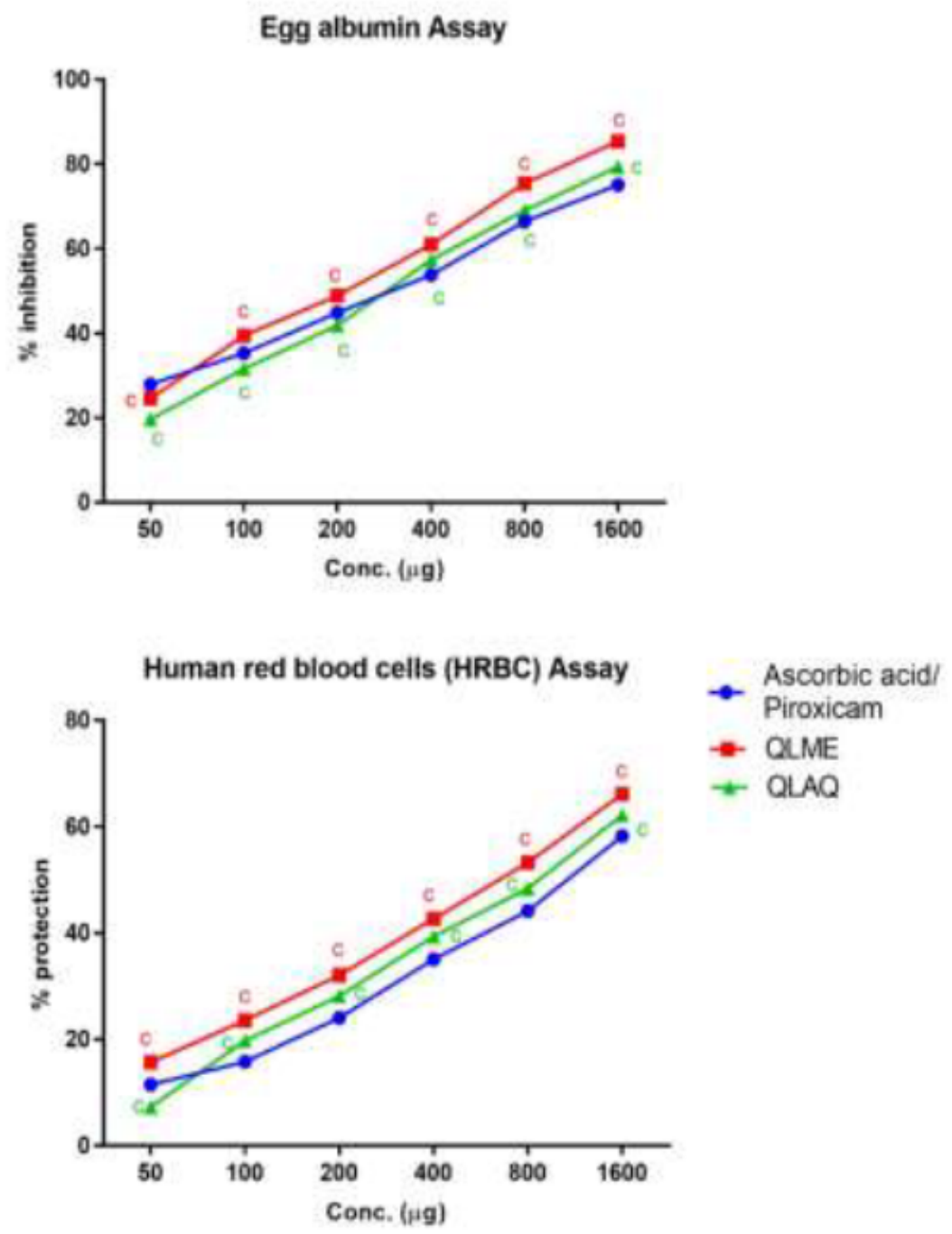

\section{Figure 1}

In-vitro anti-oxidant and anti-inflammatory activity of Quercus leucotrichophora extracts

Results presented as mean \pm S.D $(n=3)$. One-way ANOVA; Dunnett's test; ' $c$ ' $(p<0.0001)$ in contrast to SC. 


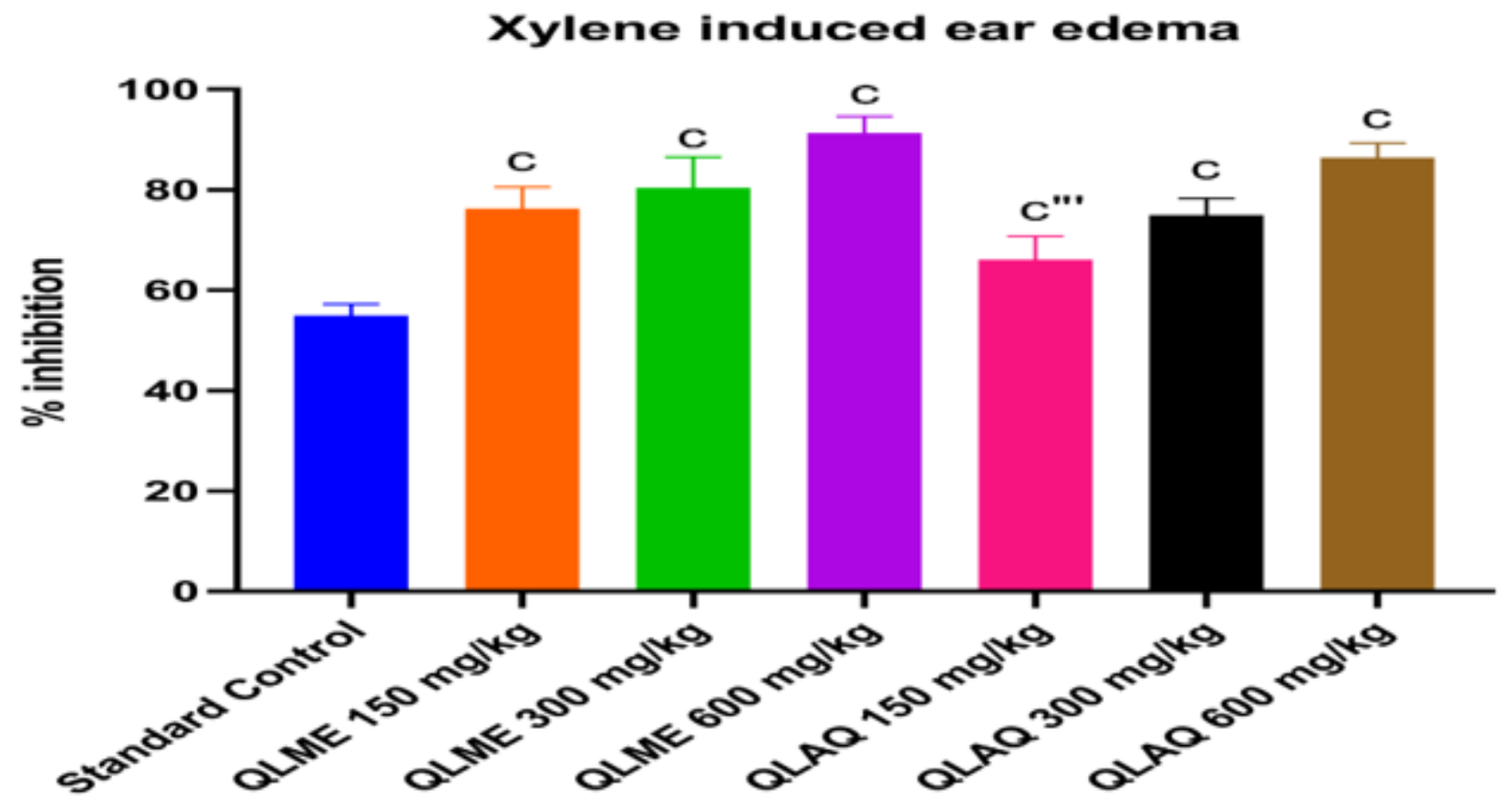

Figure 2

The effect of Quercus leucotrichophora extracts in xylene induced ear edema

Results presented as mean \pm S.D. $(n=6)$; One-way ANOVA subsequently Dunnett's test; $c^{\prime \prime \prime}, c: p<0.001$, 0.0001 in contrast to Standard control. 


\section{Arthtritic index}

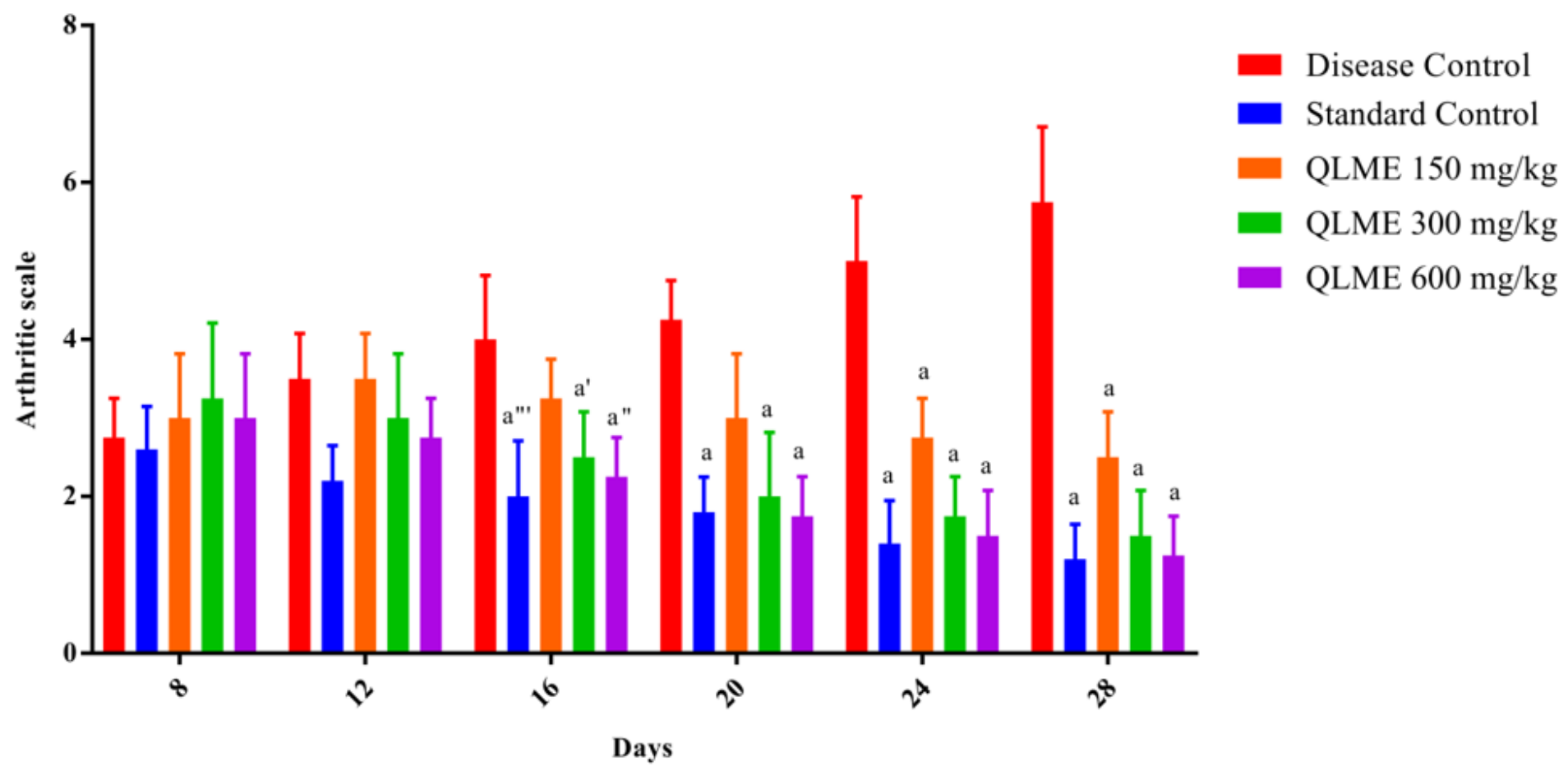

Figure 3

The effect of Quercus leucotrichophora on the arthritic index

Results as mean \pm S.D. $(n=6)$; Two-way ANOVA; Tukey's test; a', a", a"' and $a: p<0.05,0.01,0.001,0.0001$ to Disease control. Treatment groups were insignificant in comparison to standard control. 
TLC count

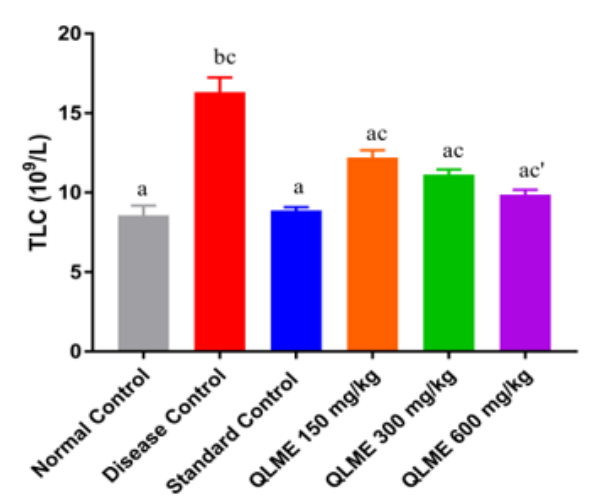

C-reactive protein (CRP)

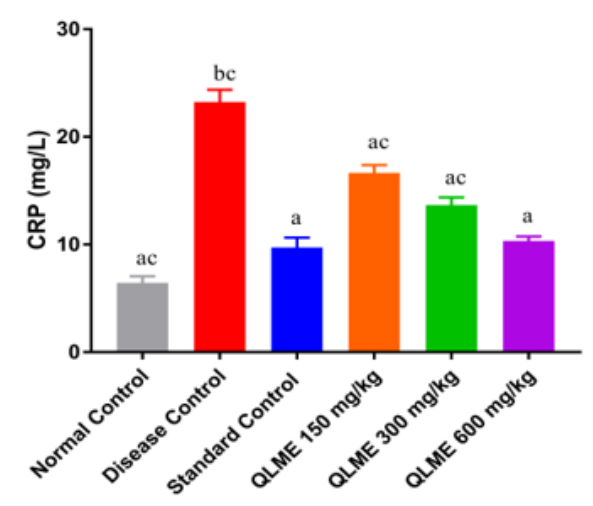

RBC's count

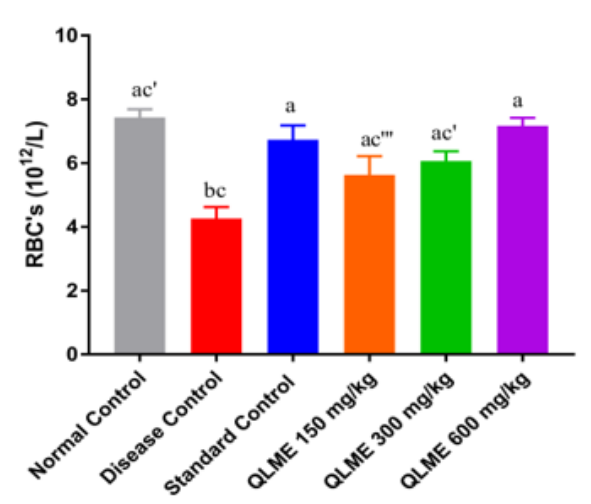

Rheumatoid Factor (RF)

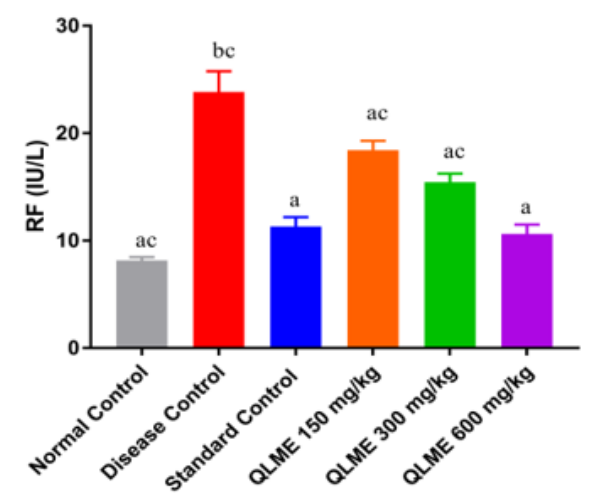

Platelets count

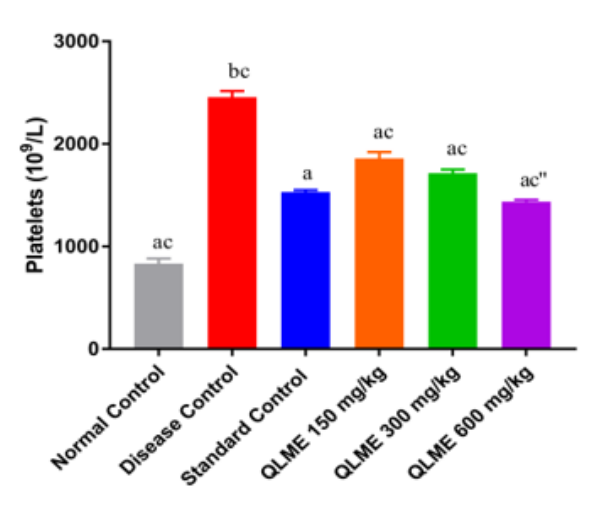

Effect on ESR

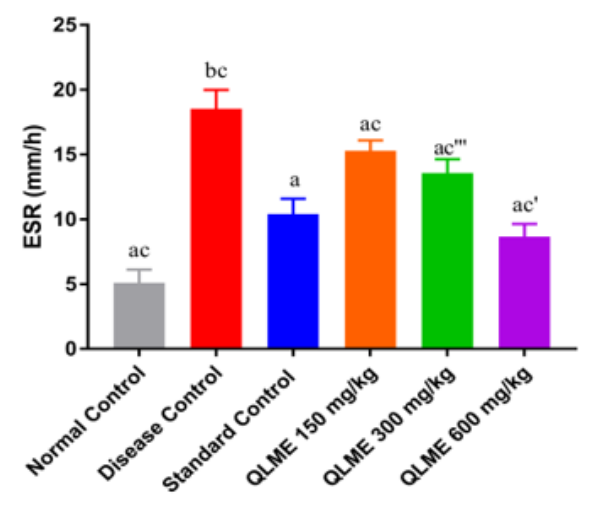

Figure 4

The effects of Quercus leucotrichophora extract on blood parameters in CFA induced arthritis

Data as mean \pm S.D $(n=6)$; One-way ANOVA; Tukey's test; 'a': $p<0.05$ to Disease control, 'b': $p<0.0001$ varied from Normal control and ' $c$ ' from Standard control. 

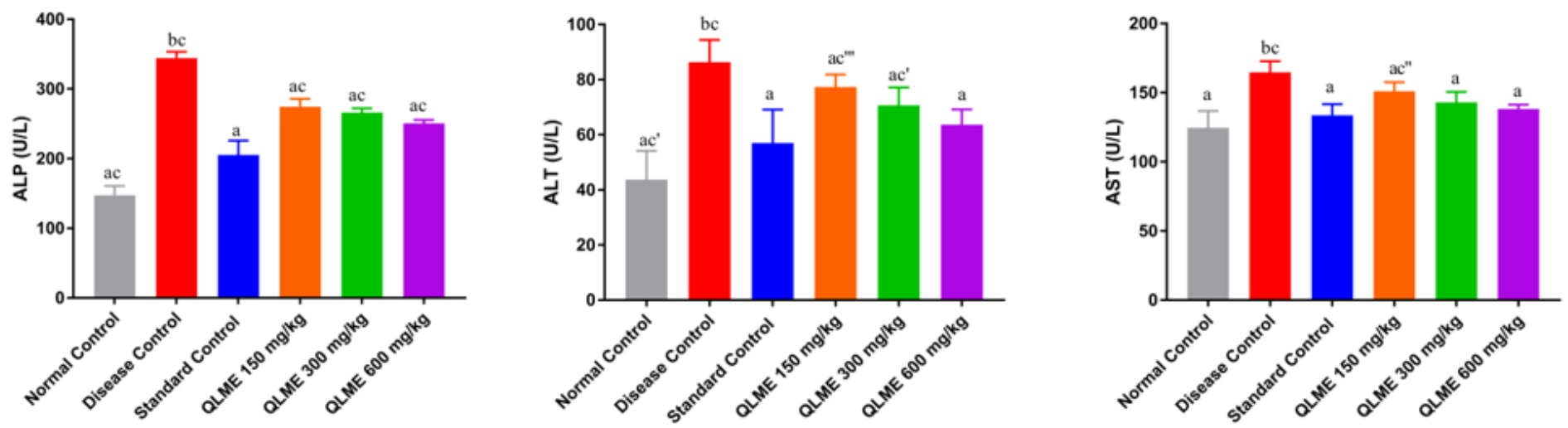

Creatinine

Hemoglobin

Blood Urea
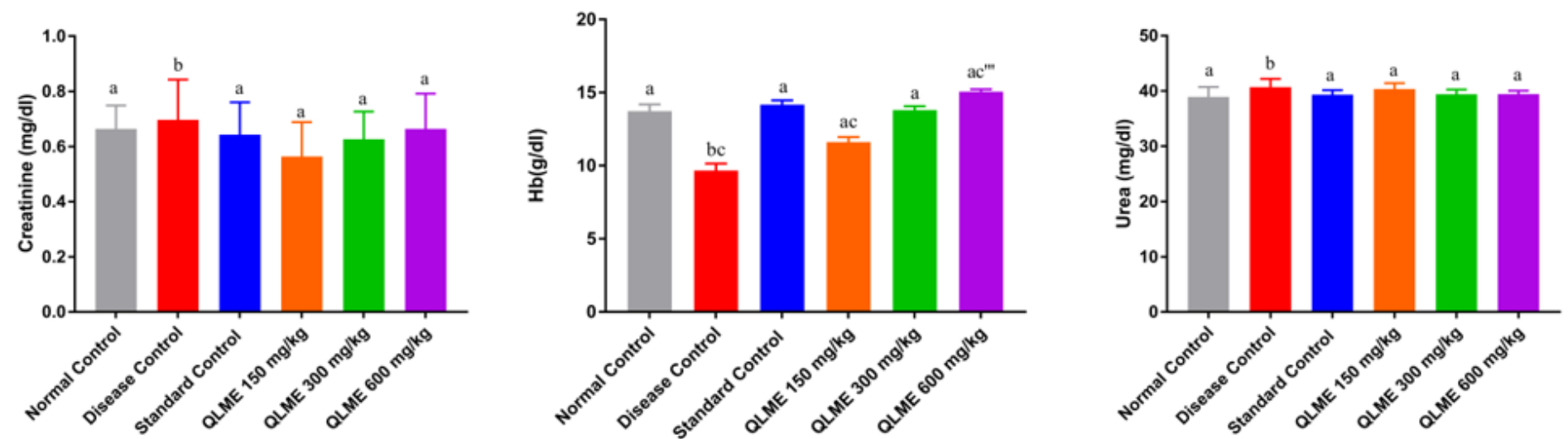

Figure 5

The effects of Quercus leucotrichophora extract on various blood parameters in CFA induced arthritis

Data as mean \pm S.D $(n=6)$. One-way ANOVA; Tukey's test; a': $p<0.05$ to Disease control, 'b': $p<0.0001$ varied from Normal control and ' $c$ ' from Standard control. 
Effect on spleen weight

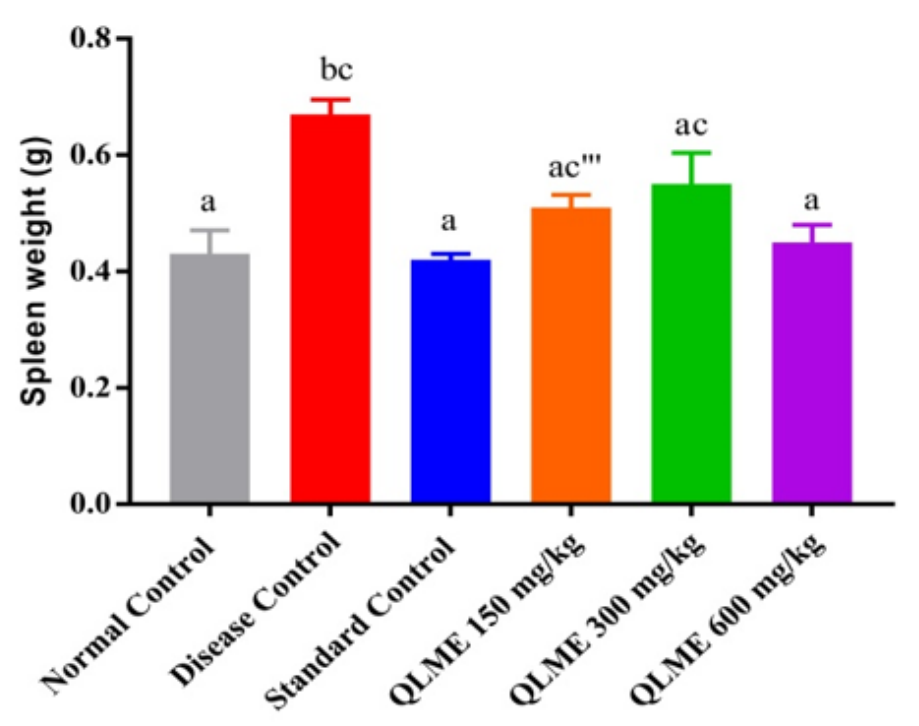

Effect on thymus weight

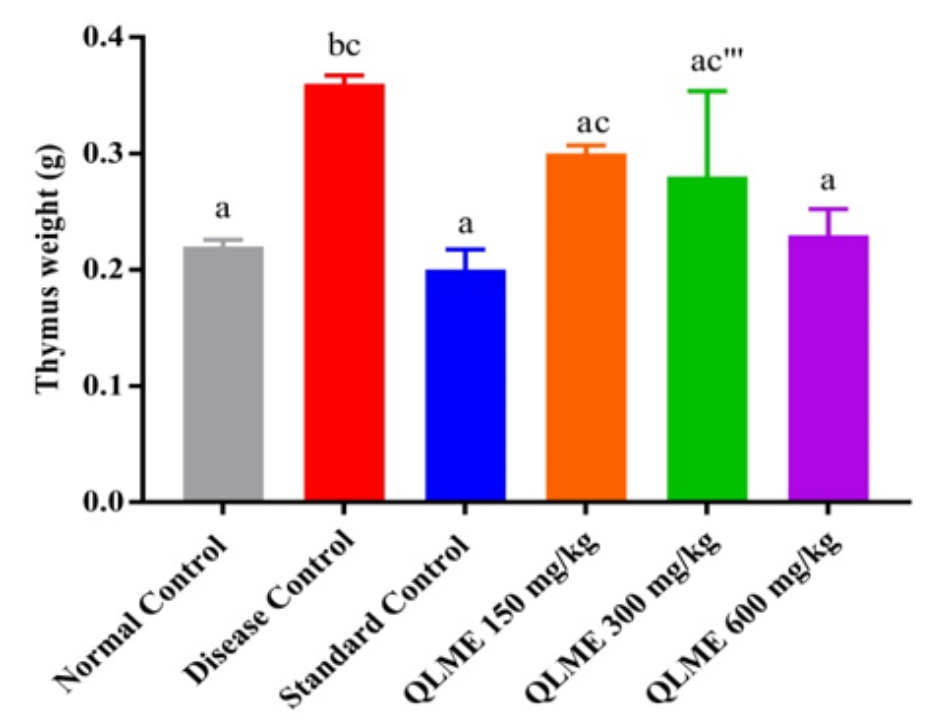

Figure 6

The effects of Quercus leucotrichophora on immune organ weight Results as mean \pm S.D. $(n=6)$; One-way ANOVA; Tukey's test; 'a': $p<0.0001$ to Disease control. 'b' $p<0.0001$ to Normal control and c'", $c$ : $p<0.001$, 0.0001 to Standard group. 

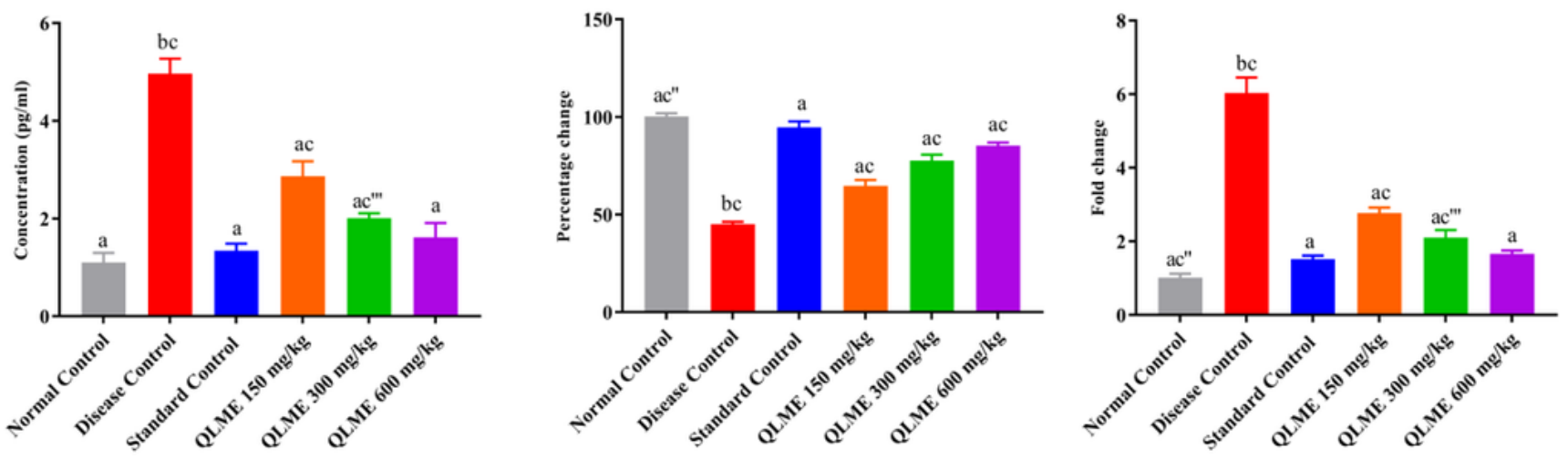

IL-10

IL-1 $\beta$

NF-KB
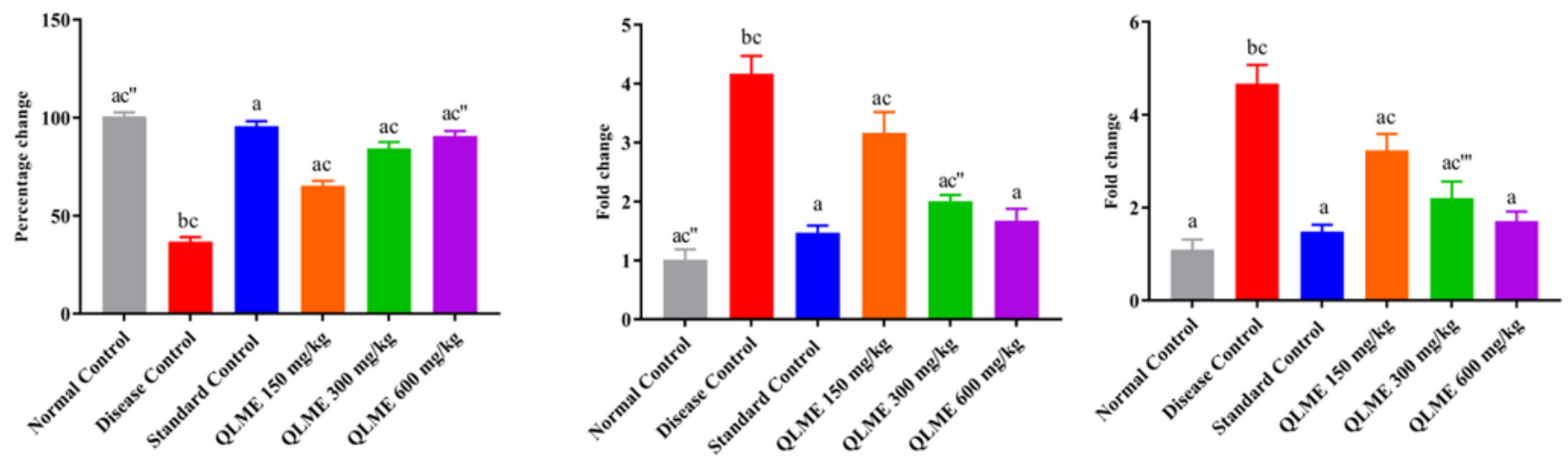

$\mathrm{I}-\kappa \mathrm{B} \alpha$

COX-2
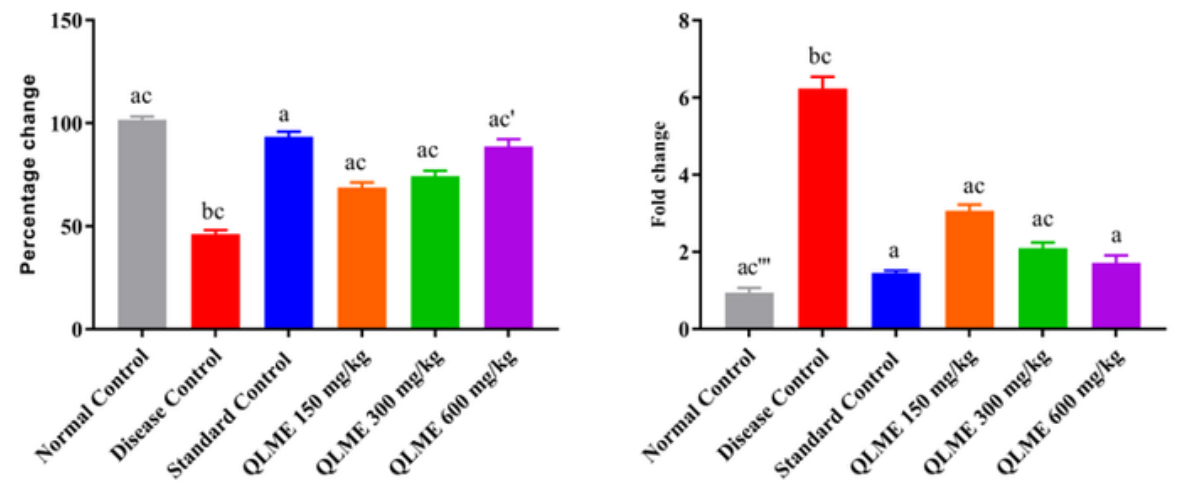

Figure 7

\section{Effects of Quercus leucotrichophora extract on inflammatory biomarkers}

Results as mean \pm S.D. One-way ANOVA; Tukey's test; 'a': $p<0.0001$ to Disease control and ' $b$ ': $p<0.0001$ from Normal control. c', c", c'”, c: $p<0.05,0.01,0.001,0.0001$ to Standard control. 
SOD activity

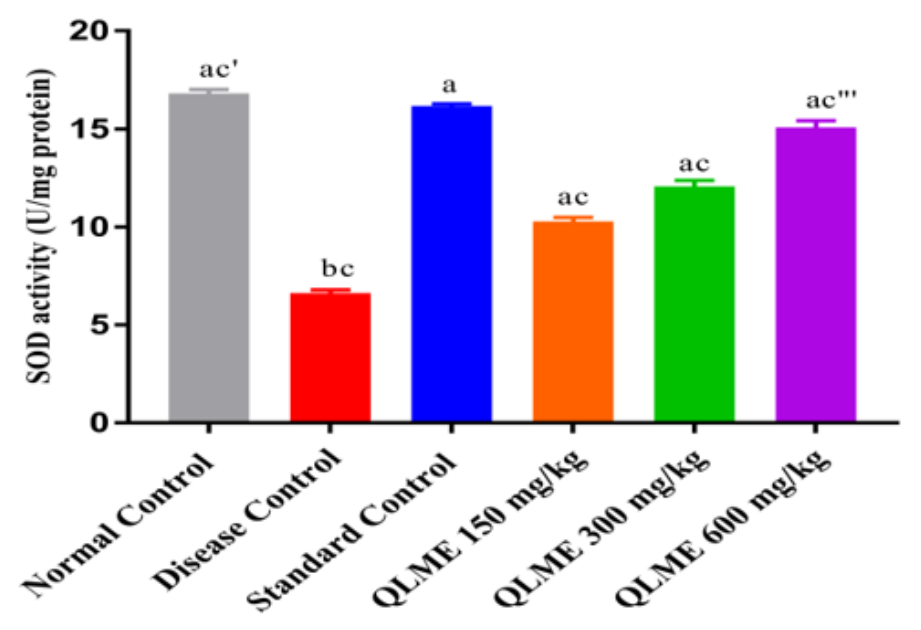

CAT activity

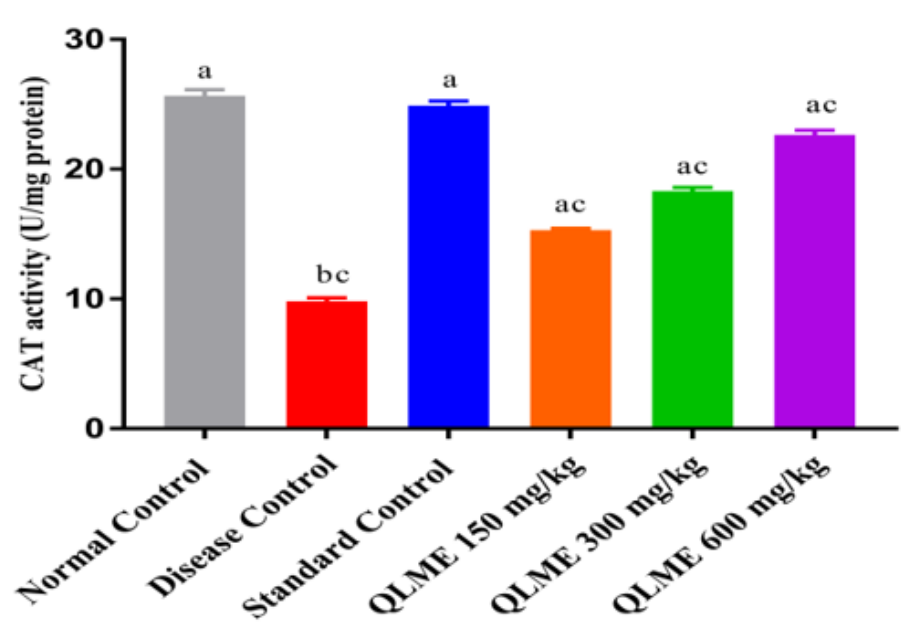

MDA level

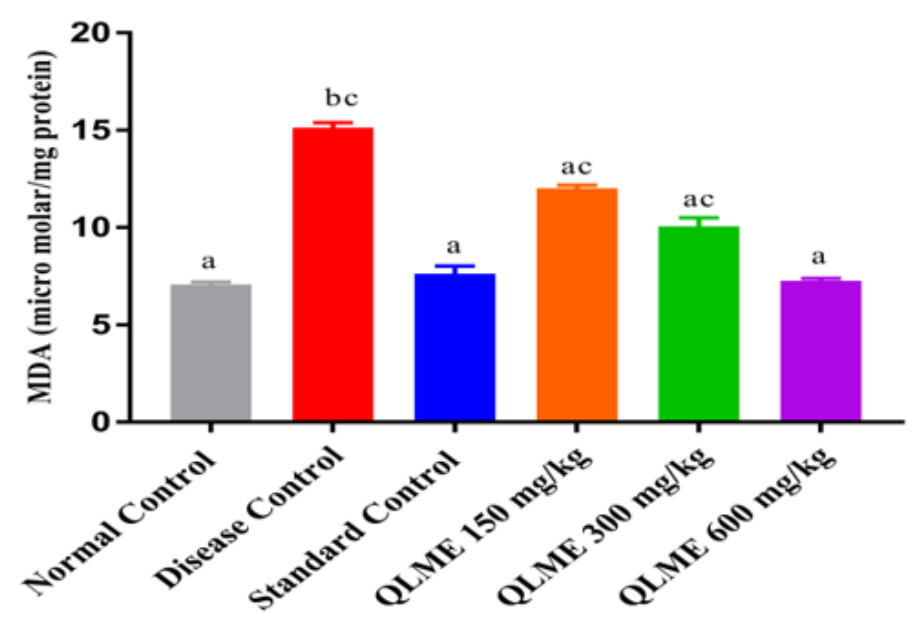

Figure 8

\section{Effects of Quercus leucotrichophora extract on oxidative stress biomarkers}

Results as mean \pm S.D. One-way ANOVA; Tukey's test; 'a' significantly $(p<0.0001)$ different from Disease control and ' $b$ ' varied considerably $(p<0.0001)$ to Normal control and $c^{\prime}, c^{\prime \prime \prime}, c: p<0.05,0.001,0.0001$ to Standard control. 

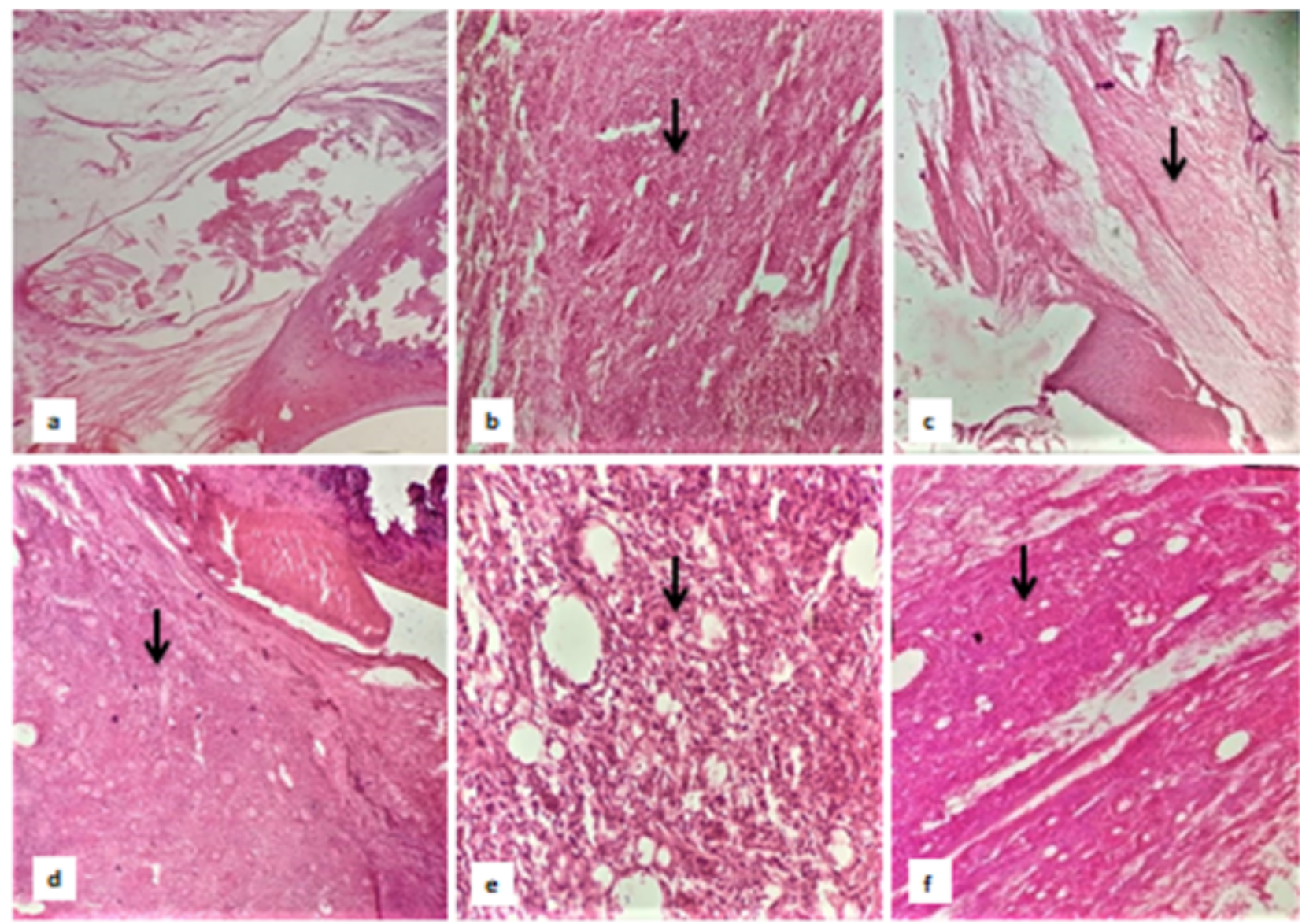

Figure 9

The effect of Quercus leucotrichophora on histopathology of CFA induced arthritic rats

(a) Normal group, (b) Diseased group, (c) Standard group, (d, e, f) QLME at 150, 300 and $600 \mathrm{mg} / \mathrm{kg}$ respectively. $\downarrow$ shows inflammation.

\section{Supplementary Files}

This is a list of supplementary files associated with this preprint. Click to download.

- GraphicalAbstract.png 